\title{
Biomarkers for cognitive decline in patients with diabetes mellitus: evidence from clinical studies
}

\author{
Xue Zhao ${ }^{1, *}$, Qing Han ${ }^{2, *}$, You Lv ${ }^{1}$, Lin Sun ${ }^{1}$, Xiaokun Gang ${ }^{1}$ and Guixia Wang ${ }^{1}$ \\ ${ }^{1}$ Department of Endocrinology and Metabolism, The First Hospital of Jilin University, Changchun, 130021, Jilin Province, China \\ ${ }^{2}$ Hospital of Orthopedics, The Second Hospital of Jilin University, Changchun, 130021, Jilin Province, China \\ *These authors contributed equally to this work \\ Correspondence to: Guixia Wang, email: gwang168@jlu.edu.cn \\ Xiaokun Gang, email: insightful@126.com
}

Keywords: diabetes; cognitive decline; diagnosis; biomarkers

Received: July 27, $2017 \quad$ Accepted: October 30, 2017

Published: December 14, 2017

Copyright: Zhao et al. This is an open-access article distributed under the terms of the Creative Commons Attribution License 3.0 (CC BY 3.0), which permits unrestricted use, distribution, and reproduction in any medium, provided the original author and source are credited.

\section{ABSTRACT}

Diabetes mellitus is considered as an important factor for cognitive decline and dementia in recent years. However, cognitive impairment in diabetic patients is often underestimated and kept undiagnosed, leading to thousands of diabetic patients suffering from worsening memory. Available reviews in this field were limited and not comprehensive enough. Thus, the present review aimed to summarize all available clinical studies on diabetic patients with cognitive decline, and to find valuable biomarkers that might be applied as diagnostic and therapeutic targets of cognitive impairment in diabetes. The biomarkers or risk factors of cognitive decline in diabetic patients could be classified into the following three aspects: serum molecules or relevant complications, functional or metabolic changes by neuroimaging tools, and genetic variants. Specifically, factors related to poor glucose metabolism, insulin resistance, inflammation, comorbid depression, micro-/macrovascular complications, adipokines, neurotrophic molecules and Tau protein presented significant changes in diabetic patients with cognitive decline. Besides, neuroimaging platform could provide more clues on the structural, functional and metabolic changes during the cognitive decline progression of diabetic patients. Genetic factors related to cognitive decline showed inconsistency based on the limited studies. Future studies might apply above biomarkers as diagnostic and treatment targets in a large population, and regulation of these parameters might shed light on a more valuable, sensitive and specific strategy for the diagnosis and treatment of cognitive decline in diabetic patients.

\section{INTRODUCTION}

Diabetes mellitus has become one of the most troubling health problems along with the rapid development of social economy. Data from International Diabetes Federation (IDF) showed that that prevalence of diabetes and impaired glucose tolerance (IGT) might reach $8.0 \%$ and $10.1 \%$ in 2035 . As for old people, over $26 \%$ of Americans ( $>65$ years old) were suffering from diabetes mellitus based on the report from American Diabetes Association (ADA) [1]. Moreover, the increased prevalence of diabetes is closely associated with increased risk of all-cause mortality, including ischemic heart disease, stroke and cancer.
Diabetes is known as an important risk factor for cognitive decline and dementia [2-4]. Comparing with patients without diabetes, diabetic patients had $39 \%$ increased risk of Alzheimer's disease and $47 \%$ increased risk of dementia [5, 6]. Multiple changes on brain metabolites and brain structures have been reported in patients with diabetes [7]. Thus, the prevalence of cognitive decline is closely linked to diabetes and its progression. However, the cognitive impairment induced by diabetes is often underestimated and kept undiagnosed, leading to thousands of diabetic people suffering from the worsening memory. Thus, targeting diabetes-related brain dysfunction and to explore valuable biomarkers for 
cognitive decline at early stage are critical problems to be solved urgently [8].

Studies have reported that multiple molecules or risk factors were associated with cognitive decline in patients with diabetes. Most reviews just summarized limited relevant biomarkers, few articles comprehensively summed up available evidence on cognitive decline in diabetes. Based on above, we aimed to explore the efficient biomarkers related to early cognitive decline in patients with diabetes and thoroughly summarized available relevant articles, which might be useful for the diagnosis and therapy monitoring of cognitive impairment in patients with diabetes. After carefully analysis, the biomarkers or risk factors of cognitive decline in diabetic patients could be classified into the following three aspects: serum molecules or relevant complications, functional or metabolic changes by neuroimaging tools, and genetic variants (Figure 1). More concretely, parameters related to glucose metabolism, inflammation, comorbid depression and vascular diseases, as well as adipokines have shown significant alterations at the early stage of cognitive decline in diabetes [9-11]. Modern brain imaging technology provides a good platform to detect slight changes in cerebral metabolism and brain structures, such as functional magnetic resonance imaging (fMRI) and magnetic resonance spectroscopy (MRS) [12]. All these early-warning signals presented during cognitive decline process in diabetic patients should be paid great attention [8]. These molecules or changes also shed light on the pathogenesis of diabetes-associated brain damages and the possibility of therapy monitoring in the near future.

\section{Early biomarkers for cognitive decline in diabetes}

\section{Association of changed molecules related to glucose metabolism with cognitive decline in diabetic patients}

Glucose metabolism is the most frequently affected factor during the development of diabetes. The poor glycemic control in diabetic patients could accelerate the appearance of micro/macro vascular complications. Factors linked to glucose metabolism were reported to be associated with cognitive impairment in diabetic patients (Table 1). Zhou et al. [13] explored the clinical characteristics related to cognitive decline on 114 diabetic patients with mild cognitive impairment (MCI) and 83 subjects with normal cognition. Negative correlations were observed between MMSE scores and 2h-glucose level $(P<0.001)$ as well as $C$-peptide $(P=0.001)$, and these parameters were independent risk factors for impaired cognition in patients with diabetes. Besides these, factors such as older age, female, higher HbAlc level, DM duration and poorer education were correlated with severe cognitive decline in diabetic patients in other studies [14, 15-17]. Study from Kinoshita et al. [18] also revealed that glycol-albumin(GA)/HbA1c ratio might be an easy and helpful biomarker for cognitive performance in 88 elderly Japanese diabetic patients. Meanwhile, some studies reported that the fluctuation of glucose level was related to cognition function. Cui et al. provided the evidence on the impacts of glycemic variability $(\mathrm{GV})$ on brain atrophy as well as cognitive decline degree in 26 diabetic patients based on $72 \mathrm{~h}$ continuous glucose monitoring data [19]. The results showed less gray matter and poorer learning and memory function were found in patients with greater glycemic variability $(P<0.05)$. Thus, to keep glycemia in a stale status without great variability is a good way to prevent cognitive decline in diabetes managements.

Uncontrolled glucose is usually accompanied by frequent hypoglycemic events [20]. Studies have shown that hypoglycemic episodes were closely related to neural damages in the regions of hippocampus and cerebral cortex [21]. Chin et al. [22] presented their latest results on the elderly Korean diabetic patients $(n=1,957)$, illustrating that patients with frequently hypoglycemic events had a significantly higher risk of developing

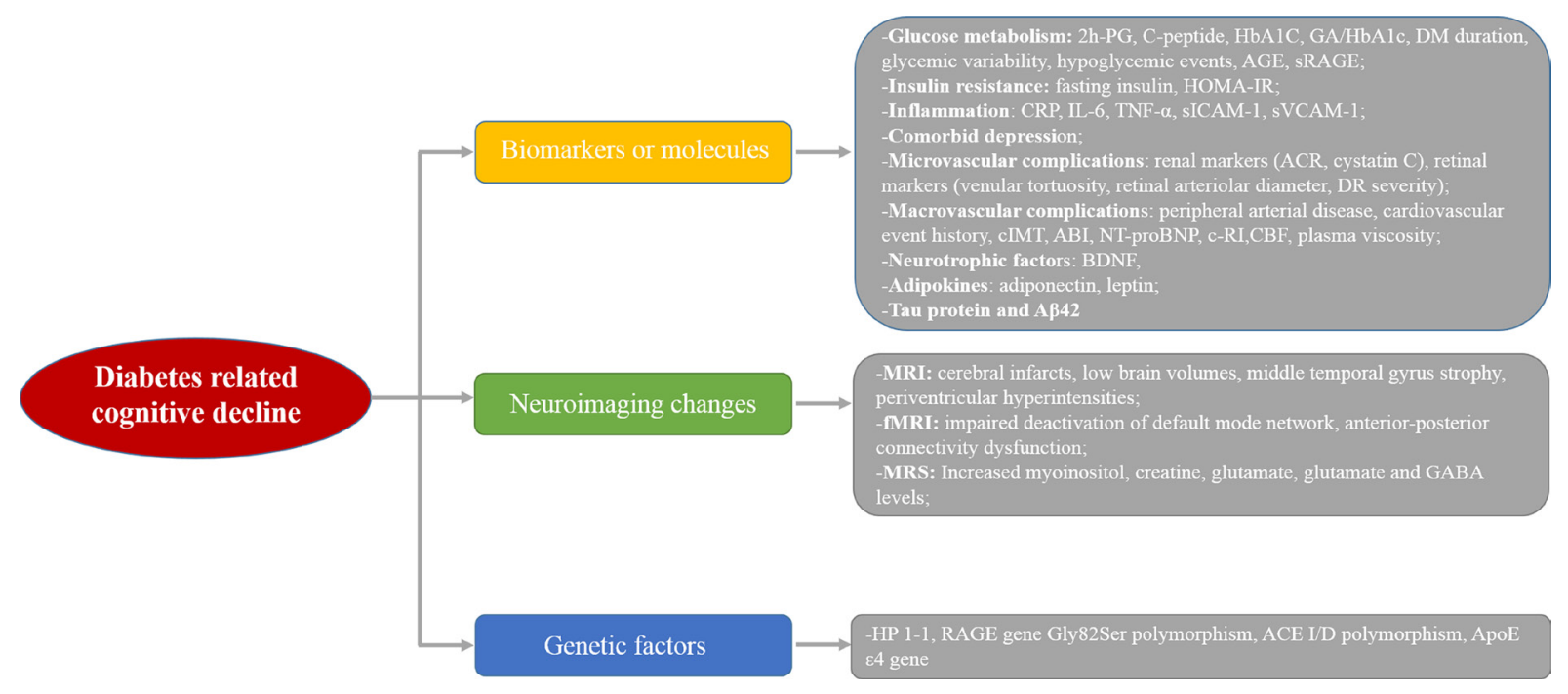

Figure 1: The diagram of possible biomarkers in diabetes-related cognitive decline. 
Table 1: Details about the studies focusing on the relationship between glucose parameters and cognitive function in diabetic patients

\begin{tabular}{|c|c|c|c|c|c|c|c|}
\hline Study & Population & Design & Number & Mean age & Glucose variables & $\begin{array}{l}\text { Cognitive } \\
\text { measure }\end{array}$ & $\begin{array}{l}\text { Association with } \\
\text { cognition }\end{array}$ \\
\hline Zhou et al [13] & T2DM; China & $\begin{array}{l}\text { Cross-sectional, } \\
\text { observational }\end{array}$ & 197 & $\begin{array}{l}66.92 \pm \\
8.95\end{array}$ & $\begin{array}{l}\text { FPG; 2h-PG; FINS; } \\
\text { 2h-INS; FCP; HbA1c }\end{array}$ & $\begin{array}{l}\text { MMSE; } \\
\text { AVLT; } \\
\text { CDR; } \\
\text { SCWT }\end{array}$ & $\begin{array}{l}\text { Negative correlation } \\
\text { between } 2 \mathrm{~h}-\mathrm{PG} \text { and } \\
\text { FCP and MMSE score. }\end{array}$ \\
\hline $\begin{array}{l}\text { Moulton et al } \\
{[14]}\end{array}$ & T2DM; UK & $\begin{array}{l}\text { Cross-sectional, } \\
\text { observational }\end{array}$ & 1680 & $56.10 \pm 11$ & $\begin{array}{l}\text { FCP; HbA1c; age; gender; } \\
\text { BMI; }\end{array}$ & TICS-M & $\begin{array}{l}\text { Negative association } \\
\text { between age, } \\
\text { female,HbA1c and } \\
\text { TICS-M score }\end{array}$ \\
\hline Bruce et al [15] & $\begin{array}{l}\text { T2DM; } \\
\text { Australia }\end{array}$ & $\begin{array}{l}\text { Retrospective, } \\
\text { observational }\end{array}$ & 335 & $\begin{array}{l}57.50 \pm \\
9.2\end{array}$ & $\begin{array}{l}\text { FCP; age; DM duration; } \\
\text { HbA1c }\end{array}$ & $\begin{array}{l}\text { MMSE; } \\
\text { CDR }\end{array}$ & $\begin{array}{l}\text { Age as independent } \\
\text { risk factor for cognitive } \\
\text { decline; negative } \\
\text { correlation between } \\
\text { cognition and FCP and } \\
\text { DM duration }\end{array}$ \\
\hline $\begin{array}{l}\text { Kinoshita et al } \\
{[18]}\end{array}$ & T2DM; Japan & $\begin{array}{l}\text { Cross-sectional, } \\
\text { observational }\end{array}$ & 88 & $\begin{array}{l}74.92 \pm \\
6.44\end{array}$ & $\begin{array}{l}\text { HbA1c; FPG; FINS; } \\
\text { GA;GA/HbA1c }\end{array}$ & $\begin{array}{l}\text { MMSE; } \\
\text { HDS-R }\end{array}$ & $\begin{array}{l}\mathrm{GA} / \mathrm{HbA} 1 \mathrm{c} \text { as } \\
\text { independent risk factor } \\
\text { for cognitive decline; }\end{array}$ \\
\hline Cui et al [19] & T2DM; US & $\begin{array}{l}\text { Cross-sectional, } \\
\text { observational }\end{array}$ & 69 & $\begin{array}{l}65.40 \pm \\
9.2\end{array}$ & $\begin{array}{l}\text { FPG; HbA1c; DM } \\
\text { duration; CGM }\end{array}$ & $\begin{array}{l}\text { MMSE; } \\
\text { HVLT }\end{array}$ & $\begin{array}{l}\text { Negative correlation } \\
\text { between greater } \\
\text { glycemic variability } \\
\text { and cognition }\end{array}$ \\
\hline Ma et al [17] & T2DM; China & Cohort study & 1480 & $75.3 \pm 5.9$ & $\begin{array}{l}\text { HbA1c; age; gender; DM } \\
\text { duration; DM treatment }\end{array}$ & Not shown & $\begin{array}{l}\text { age }>75 \text { years and } \\
\text { longer durations of } \\
\text { diabetes as major risk } \\
\text { factors for MCI and } \\
\text { dementia }\end{array}$ \\
\hline Chin et al [22] & T2DM; Korea & $\begin{array}{l}\text { KNDP cohort } \\
\text { study }\end{array}$ & 4540 & $67.5 \pm 5.5$ & $\begin{array}{l}\text { FPG; HbA1c; } \\
\text { hypoglycemic events }\end{array}$ & Not shown & $\begin{array}{l}\text { Linear trend between } \\
\text { hypoglycemic events } \\
\text { and risk of dementia }\end{array}$ \\
\hline Ryan et al [23] & T1DM; US & $\begin{array}{l}\text { Cross-sectional, } \\
\text { observational }\end{array}$ & 244 & $55.2 \pm 8.3$ & $\begin{array}{l}\text { HbA1c; hypoglycemic } \\
\text { events }\end{array}$ & $\begin{array}{l}\text { Mental } \\
\text { efficiency } \\
\text { tests; } \\
\text { nonverbal } \\
\text { memory } \\
\text { tests; verbal } \\
\text { memory } \\
\text { tests }\end{array}$ & $\begin{array}{l}\text { Severe hypoglycemic } \\
\text { events associated } \\
\text { with poorer cognitive } \\
\text { function }\end{array}$ \\
\hline Wang et al [24] & T2DM; China & $\begin{array}{l}\text { Cross-sectional, } \\
\text { observational }\end{array}$ & 167 & $\begin{array}{l}60.15 \pm \\
7.47\end{array}$ & $\begin{array}{l}\text { sRAGE; AGE-P; HbAlc; } \\
\text { FPG; FCP; } 2 \mathrm{~h}-\mathrm{CP}\end{array}$ & $\begin{array}{l}\text { MoCA; } \\
\text { DST; TMT; } \\
\text { CDR; CDT; } \\
\text { ST; VFT }\end{array}$ & $\begin{array}{l}\text { Negative correlation } \\
\text { for sRAGE; Positive } \\
\text { correlation for AGE-P } \\
\text { with cognitive function }\end{array}$ \\
\hline $\begin{array}{l}\text { Ciebiada et al } \\
{[25]}\end{array}$ & $\begin{array}{l}\text { T2DM; } \\
\text { Poland }\end{array}$ & $\begin{array}{l}\text { Cross-sectional, } \\
\text { observational }\end{array}$ & 276 & $73.6 \pm 4.8$ & Serum AGEs, RAGE & MoCA & $\begin{array}{l}\text { Increased AGEs, } \\
\text { RAGE in MCI patients }\end{array}$ \\
\hline
\end{tabular}

Notes: T2DM: type 2 diabetes mellitus; FPG: fasting plasma glucose; 2h-PG: 2h-psprandial glucose; FINS: fasting insulin; FCP: fasting C-peptide; BMI: body mass index; GA: glycoalbumin; sRAGE: soluble receptor for AGEs; AGE-P: Advanced glycation end products-peptides; MMSE: Mini-Mental State Examination; AVLT: Auditory Verbal Learning Test; CDR: Clinical Dementia Rating; SCWT: Stroop Color Words Test; TICS-M: telephone interview for cognitive status; HDS-R: Hasegawa dementia scale-revised; HVLT: Hopkins Verbal Learning Test-Revised; KNDP: Korea National Diabetes Program; TMT: Trail Making Test; DSST: Digit Symbol Substitution Test; MoCA: Montreal cognitive assessment; DST: digit span test; CDT: the clock drawing test; ST: similarities test; VFT: verbal fluency test; MCI: mild cognitive impairment.

dementia $(P=0.0286)$. Besides, the increased dementia risk is related to more severe hypoglycemic events. Thus, there is a vicious circle between dementia and diabetes, contributing to the aggravation of diabetes strikingly as a result. Similar results were reported by Ryan et al. [23], they demonstrated negative relationship between cognitive scores and the hypoglycemia episode in the past year $(\beta=$
$-0.360)$. Thus, to prevent the appearance of hypoglycemic events is an effective way to protect diabetic patients from suffering worsening cognitive function. Future studies should expand the sample size and follow-up duration to validate above findings.

Advanced glycation end products (AGEs) refer to a group of chemicals or molecules formed by the non- 
Table 2: Details about the studies focusing on the relationship between insulin resistance and cognitive function in patients with diabetes

\begin{tabular}{|c|c|c|c|c|c|c|c|}
\hline Study & Population & Design & Number & Mean age & $\begin{array}{l}\text { Insulin } \\
\text { resistance }\end{array}$ & $\begin{array}{l}\text { Cognitive } \\
\text { measure }\end{array}$ & Association with cognition \\
\hline $\begin{array}{l}\text { Ma et al. } \\
{[26]}\end{array}$ & T2DM; China & $\begin{array}{l}\text { Cross- } \\
\text { sectional, } \\
\text { observational }\end{array}$ & 212 & $70.7 \pm 9.73$ & $\begin{array}{l}\text { FPG, FINS, } \\
\text { HOMA-IR, } \\
\text { BMI }\end{array}$ & MMSE & $\begin{array}{l}\text { FINS, HOMA-IR and } \\
\text { education level as } \\
\text { independent risk factors for } \\
\text { cognitive decline; }\end{array}$ \\
\hline $\begin{array}{l}\text { Hishikawa } \\
\text { et al. [27] }\end{array}$ & T2DM; Japan & $\begin{array}{l}\text { Cross- } \\
\text { sectional, } \\
\text { observational }\end{array}$ & 182 & $64.7 \pm 18.0$ & $\begin{array}{l}\text { FPG; } \\
\text { HbA1c; } \\
\text { HOMA-IR }\end{array}$ & $\begin{array}{l}\text { MMSE; } \\
\text { HDS-R; } \\
\text { MoCA; FAB; }\end{array}$ & $\begin{array}{l}\text { Negative association } \\
\text { between HOMA-IR and } \\
\text { MoCA score }\end{array}$ \\
\hline $\begin{array}{l}\text { Zhong et al. } \\
{[28]}\end{array}$ & T2DM; China & Cohort study & 328 & $57.50 \pm 9.2$ & $\begin{array}{l}\text { FPG; FINS; } \\
\text { HOMA-IR }\end{array}$ & $\begin{array}{l}\text { MMSE, } \\
\text { MOCA, } \\
\text { CDR, GDS; } \\
\text { ADL }\end{array}$ & $\begin{array}{l}\text { Negative correlation } \\
\text { between FINS, HOMA-IR } \\
\text { and MMSE score as well as } \\
\text { delayed memory }\end{array}$ \\
\hline $\begin{array}{l}\text { Umegaki et } \\
\text { al. [29] }\end{array}$ & DM; Japan & $\begin{array}{l}\text { Cross- } \\
\text { sectional, } \\
\text { observational }\end{array}$ & 444 & $72.4 \pm 4.7$ & $\begin{array}{l}\text { HbA1c; } \\
\text { HOMA-IR }\end{array}$ & $\begin{array}{l}\text { MMSE, } \\
\text { semantic } \\
\text { fluency, digit } \\
\text { span, digit } \\
\text { symbol, } \\
\text { TMT-A, } \\
\text { TMT-B }\end{array}$ & $\begin{array}{l}\text { Negative correlation } \\
\text { between HOMA-IR and } \\
\text { logical memory } 2 \text { and } \\
\text { MMSE score; }\end{array}$ \\
\hline $\begin{array}{l}\text { Ekblad et al. } \\
{[30]}\end{array}$ & IR; Finland & Cohort study & 5935 & $52.5 \pm 14.7$ & $\begin{array}{l}\text { FPG; } \\
\text { HbA1c; } \\
\text { TG; } \\
\text { HOMA-IR; } \\
\text { HDL }\end{array}$ & $\begin{array}{l}\text { VFT; WLL; } \\
\text { WLDR; RT; } \\
\text { VC }\end{array}$ & $\begin{array}{l}\text { Negative association } \\
\text { between HOMA-IR and } \\
\text { verbal fluency test score in } \\
\text { women, not men }\end{array}$ \\
\hline $\begin{array}{l}\text { Willette et } \\
\text { al. [31] }\end{array}$ & IR; US & $\begin{array}{l}\text { Cross- } \\
\text { sectional, } \\
\text { observational }\end{array}$ & 280 & $75.23 \pm 7.13$ & $\begin{array}{l}\text { FPG; FINS; } \\
\text { HOMA-IR; } \\
\text { BMI; Age }\end{array}$ & MMSE & $\begin{array}{l}\text { Hypermetabolism in medial } \\
\text { temporal lobe in MCI } \\
\text { patients; Positive association } \\
\text { between FDG level and IR } \\
\text { in MTL region. }\end{array}$ \\
\hline $\begin{array}{l}\text { Geijselaers } \\
\text { et al. [35] }\end{array}$ & $\begin{array}{l}\text { IR; } \\
\text { Netherlands }\end{array}$ & $\begin{array}{l}\text { Cross- } \\
\text { sectional, } \\
\text { observational }\end{array}$ & 641 & $62 \pm 8$ & $\begin{array}{l}\text { FINS; } \\
\text { C-peptide; } \\
\text { HOMA- } \\
\text { IR; BMI; } \\
\text { Age; FPG; } \\
\text { HbA1c }\end{array}$ & $\begin{array}{l}\text { memory, } \\
\text { executive } \\
\text { function, } \\
\text { attention, } \\
\text { information } \\
\text { processing } \\
\text { speed }\end{array}$ & $\begin{array}{l}\text { FINS, C-peptide, HOMA-IR } \\
\text { not associated with } \\
\text { cognitive performance }\end{array}$ \\
\hline $\begin{array}{l}\text { Neergaard et } \\
\text { al. [32] }\end{array}$ & $\begin{array}{l}\text { MetS; } \\
\text { Denmark }\end{array}$ & Cohort study & 2103 & $65.40 \pm 9.2$ & $\begin{array}{l}\text { FPG; } \\
\text { HbA1c; } \\
\text { BMI; } \\
\text { HOMA- } \\
\text { IR;FINS; } \\
\text { TG; HDL; } \\
\text { BP }\end{array}$ & $\begin{array}{l}\text { Short Blessed } \\
\text { Test; } \\
\text { category } \\
\text { fluency test }\end{array}$ & $\begin{array}{l}\text { Negative correlation } \\
\text { between FPG, HOMA-IR } \\
\text { and cognitive function }\end{array}$ \\
\hline $\begin{array}{l}\text { Brutto et al. } \\
{[34]}\end{array}$ & MetS; US & $\begin{array}{l}\text { Cross- } \\
\text { sectional, } \\
\text { observational }\end{array}$ & 212 & $69.2 \pm 7.2$ & $\begin{array}{l}\text { FPG; BP; } \\
\text { TG; age; } \\
\text { BMI; } \\
\text { education; }\end{array}$ & MoCA; & No correlation \\
\hline $\begin{array}{l}\mathrm{Ng} \text { et al. } \\
{[33]}\end{array}$ & $\begin{array}{l}\text { MetS; } \\
\text { Singapore }\end{array}$ & Cohort study & 1519 & $64.9 \pm 6.8$ & $\begin{array}{l}\text { BP; lipid } \\
\text { profiles; } \\
\text { age; } \\
\text { education; }\end{array}$ & $\begin{array}{l}\text { MMSE; } \\
\text { memory; } \\
\text { language; } \\
\text { attention; }\end{array}$ & $\begin{array}{l}\text { Increased MCI risk in } \\
\text { patients with MetS }\end{array}$ \\
\hline
\end{tabular}

Notes: T2DM: type 2 diabetes mellitus; MetS: metabolic syndrome; FPG: fasting plasma glucose; 2h-PG: 2h-psprandial glucose; FINS: fasting insulin; BMI: body mass index; TG: triglyceride; BP: blood pressure; HOMA-IR; MMSE: Mini-Mental State Examination; CDR: Clinical Dementia Rating; HDS-R: Hasegawa dementia scale-revised; TMT: Trail Making Test; MoCA: Montreal cognitive assessment; FAB: frontal assessment battery; VFT: verbal fluency test; MCI: mild cognitive impairment; WLL: word-list learning test; WLDR: wordlist delayed-recall test; RT: reaction-time test; VC: visual choice reaction-time test. 
enzymatic glycation of proteins, lipids, and nucleic acids. Excessive accumulations of AGEs are closely related to the appearance of vascular complications in diabetes. The receptor for AGE, which is RAGE, can mediate the effects of AGEs contributing to serious damages in different organs during the diabetes progression. However, the role of AGE and RAGE in diabetes related cognitive decline is unclear. Wang et al. [24] revealed decreased soluble RAGE (sRAGE) level and increased AGE-peptide level in 82 diabetic patients with MCI $(P<0.01)$. Negative association was found between sRAGE level and trail making test-B (TMT-B, $P=0.002$ ). Another study from Gorska-Ciebiada et al. [25] showed increased AGE and RAGE levels in MCI patients, which were positively correlated with HbAlc level, but inversely correlated with MoCA scores. Thus, there were increased AGEs and RAGE levels in diabetic patients with cognitive decline, indicating AGEs and RAGE might be applied as biomarkers for the appearance of cognitive decline in diabetes. However, the specificity and sensitivity of these markers were unknown.

\section{Association between insulin resistance or hyperinsulinemia with cognitive decline in diabetes}

Insulin resistance (IR) or hyperinsulinemia have generated increasing attention due to its critical role in the development of cognitive decline or dementia [26]. Clinical studies have shown the close link between IR and cognitive dysfunction in diabetic patients (Table 2). Ma et al. [17] explored their research on 212 old patients with T2DM in two subgroups (cognitive impairment $n=100$; normal cognitive group $n=112$ ). Compared with normal cognitive group, patients with impaired cognitive function presented lower education level, higher fasting insulin level and higher HOMA-IR [(6.9 \pm 1.7$)$ vs $(3.9 \pm 0.9), p$ $<0.01]$. Thus, IR and fasting could be independent risk factors for cognitive dysfunction. To discover the impact of the severity of IR on cognitive function, Hishikawa et al. [27] enrolled 182 outpatients with DM and found significantly decreased MoCA scores in 'naming', 'read list of letters' and 'delayed recall' aspects along with the deteriorating of HOMA-IR (HOMA-IR: < 1.2; 1.2-12; > 12). Similar results were reported by Zhong et al. [28]. Yuan and his colleague reported that elderly patients with hyperinsulinemia (FINS $>10.5 \mathrm{mU} / \mathrm{L} ; n=180$ ) and IR (HOMA-IR $>2.31 ; n=192$ ) had lower cognitive test scores in MMSE, MoCA, CDR, orientation, delayed memory, and attention/calculation domains. Other studies also revealed negative association between HOMAIR and cognitive impairment [29-31]. Neergaard et al. [32] discovered that patients with HOMA-IR $>2.6$ held $47 \%$ larger possibility to suffer from cognitive decline in the Prospective Epidemiological Risk Factor study $(n=2,103)$. Pin Ng et al. [33] reported that metabolic syndrome increased the risk of MCI and its progression to dementia in 1519 participants (HR: 1.46). However, inconsistent results were demonstrated by Brutto et al. [34] and Geijselaers et al. [35], they found there was no association between the existence of metabolic syndrome and cognitive impairment. The explanation for this inconsistency should be?

In conclusion, insulin resistance or hyperinsulinemia played an important role in the cognitive decline of diabetic patients. Diabetes-induced cognitive impairment might occur at the early stage of diabetes, even in IR patients without diabetes. Preventing strategies should be performed in IR patients as soon as possible. As for the mechanism of IR induced neuropathy, available studies revealed that IR might affect hippocampus plasticity, APP metabolism, tau protein metabolism and inflammation reaction $[26,36]$. All these factors might synergistically contribute to the deteriorated cognitive function in diabetic patients. However, the interactions between these influencing factors remain to be illustrated in the near future.

\section{Association between inflammatory factors and cognitive decline in diabetes}

Chronic inflammation is considered to play an important role in the development of cognitive impairment. Studies have shown the existence of enhanced inflammation in the brain of patients with dementia [37]. In patients with diabetes, cognitive decline is associated with remarkable changes in inflammatory molecules (Table 3). Marioni et al. explored the circulating inflammation markers (CRP, IL-6 and TNF- $\alpha$ ) in 1,066 patients with diabetes, demonstrating that IL-6 and TNF- $\alpha$ were associated with cognitive function. Moreover, higher level of inflammation markers were related to poorer cognitive scores after sex- and age- adjustment $(P<0.05)$ [38]. Gorska-Ciebiada et al. [39, 25] revealed increased CRP, IL-6 and TNF- $\alpha$ in patients with both diabetes and MCI. The inflammation markers were positively correlated with $\mathrm{HbAlc}$ and negatively correlated with MoCA scores. Notably, diabetic patients with both MCI and depression presented highest levels of inflammation markers (CRP, IL-6 and TNF- $\alpha$ ). As for other inflammation factors, IL-1 $\beta$ was increased in patients with MCI group when compared with normal controls [40]. Besides, soluble intercellular adhesion molecule 1 (sICAM-1), soluble vascular adhesion molecule 1(sVCAM-1) and hs-CRP in diabetic patients with MCI and diabetic patients with both MCI and depression [41]. And diabetic patients with both MCI and depression presented highest sICAM-1 and sVCAM-1 levels when compared to diabetic patients with depression, indicating inflammation factors plays an important role in the development of MCI in diabetic 
Table 3: Details about the studies focusing on the relationship between inflammation factors and cognitive function in diabetic patients

\begin{tabular}{|c|c|c|c|c|c|c|c|}
\hline Study & Population & Design & Number & $\begin{array}{l}\text { Mean } \\
\text { age }\end{array}$ & $\begin{array}{l}\text { Inflammation } \\
\text { factors }\end{array}$ & $\begin{array}{l}\text { Cognitive } \\
\text { measure }\end{array}$ & Association with cognition \\
\hline $\begin{array}{l}\text { Marioni } \\
\text { et al [38] }\end{array}$ & T2DM; UK & $\begin{array}{l}\text { Cross- } \\
\text { sectional, } \\
\text { observational }\end{array}$ & 1066 & $\begin{array}{l}67.9 \pm \\
4.2\end{array}$ & $\begin{array}{l}\text { CRP; TNF- } \alpha \text {; } \\
\text { IL-6 }\end{array}$ & $\begin{array}{l}\text { MR; LNS; } \\
\text { VFT; DST; } \\
\text { TMT; LM; } \\
\text { FACES }\end{array}$ & $\begin{array}{l}\text { Higher TNF- } \alpha \text { and IL- } 6 \\
\text { associated with poorer } \\
\text { cognitive function. }\end{array}$ \\
\hline $\begin{array}{l}\text { Gorska- } \\
\text { Ciebiada } \\
\text { et al [39] }\end{array}$ & $\begin{array}{l}\text { T2DM; } \\
\text { Poland }\end{array}$ & $\begin{array}{l}\text { Cross- } \\
\text { sectional, } \\
\text { observational }\end{array}$ & 276 & $\begin{array}{l}73.6 \pm \\
4.8\end{array}$ & $\begin{array}{l}\text { CRP, IL-6, } \\
\text { TNF- } \alpha\end{array}$ & $\mathrm{MoCA}$ & $\begin{array}{l}\text { Negative association between } \\
\text { CRP, TNF- } \alpha \text { and MoCA } \\
\text { score }\end{array}$ \\
\hline $\begin{array}{l}\text { Gorska- } \\
\text { Ciebiada } \\
\text { et al [40] }\end{array}$ & $\begin{array}{l}\text { T2DM; } \\
\text { Poland }\end{array}$ & $\begin{array}{l}\text { Cross- } \\
\text { sectional, } \\
\text { observational }\end{array}$ & 194 & $\begin{array}{l}73.2 \pm \\
4.5\end{array}$ & IL-1 $\beta$ & $\mathrm{MoCA}$ & $\begin{array}{l}\text { Increased IL- } 1 \beta \text { correlated } \\
\text { with increased risk of MCI }\end{array}$ \\
\hline $\begin{array}{l}\text { Gorska- } \\
\text { Ciebiada } \\
\text { et al }[41]\end{array}$ & $\begin{array}{l}\text { T2DM; } \\
\text { Poland }\end{array}$ & $\begin{array}{l}\text { Cross- } \\
\text { sectional, } \\
\text { observational }\end{array}$ & 219 & $\begin{array}{l}74.92 \\
\pm 6.44\end{array}$ & $\begin{array}{l}\text { hs-CRP; } \\
\text { sICAM-1; } \\
\text { SVCAM-1; }\end{array}$ & MoCA & $\begin{array}{l}\text { Increased sICAM-1 and } \\
\text { sVCAM-1 correlated with } \\
\text { increased risk of MCI }\end{array}$ \\
\hline $\begin{array}{l}\text { Chung et } \\
\text { al [42] }\end{array}$ & T2DM; US & $\begin{array}{l}\text { Cross- } \\
\text { sectional, } \\
\text { observational }\end{array}$ & 69 & $\begin{array}{l}65.40 \\
\pm 9.2\end{array}$ & $\begin{array}{l}\text { hs-CRP; } \\
\text { sICAM-1; } \\
\text { SVCAM-1; }\end{array}$ & $\begin{array}{l}\text { MMSE; } \\
\text { HVLT-R: } \\
\text { IADL }\end{array}$ & $\begin{array}{l}\text { Negative correlation } \\
\text { between hs-CRP; sICAM-1; } \\
\text { SVCAM-1 and cerebral } \\
\text { vasoreactivity, vasodilation } \\
\text { and cognition }\end{array}$ \\
\hline $\begin{array}{l}\text { Lavielle } \\
\text { et al [43] }\end{array}$ & $\begin{array}{l}\text { T2DM; } \\
\text { Mexico }\end{array}$ & $\begin{array}{l}\text { Cross- } \\
\text { sectional, } \\
\text { observational }\end{array}$ & 1712 & $\begin{array}{l}51 \pm \\
11\end{array}$ & $\begin{array}{l}\text { Rheumatoid } \\
\text { arthritis; } \\
\text { asthma }\end{array}$ & $\begin{array}{l}\text { CDT; } \\
\text { Verbal } \\
\text { fluency; } \\
\text { Calculation }\end{array}$ & $\begin{array}{l}\text { Rheumatoid arthritis and } \\
\text { asthma as risk factors for } \\
\text { MCI }\end{array}$ \\
\hline
\end{tabular}

Notes: DST: digit symbol test; FACES: Faces and Family Pictures Subtest; HADS: Hospital Anxiety and Depression Scale; LM: logical memory; LNS: letter-number sequencing; MR: matrix reasoning; TMT: Trail Making Test-Part B; VFT: Verbal Fluency Test; sICAM-1: soluble intercellular adhesion molecule 1; sVCAM-1: soluble vascular adhesion molecule 1; HVLT-R: Hopkins Verbal Learning Test-Revised; IADL: Instrumental Activities of Daily Living; MMSE: Mini-Mental State Examination; CDT: The clock drawing test free-hand format; MCI: mild cognitive impairment.

patients with depression. Besides direct influences on cognition function, inflammation can also affect cerebral vasoregulation. In 65 diabetic patients, Chung et al. [42] found that increased soluble intercellular, vascular adhesion molecules and hs-CRP were correlated with decreased cerebral vasoreactivity and vasodilation $(P=0.007-0.048)$, illustrating that inflammation could influence the brain vasoregulation and accelerate the progression of cognitive impairment in diabetes. To further validate the role of inflammation in cognitive impairment, Lavielle et al. [43] performed their study on 1,712 patients with new diagnosis of T2DM, showing that rheumatoid arthritis and asthma, two chronic inflammatory diseases, were risk factors for cognitive impairments in diabetic patients. Overall, inflammation is an important marker for diabetes-induced cognitive decline. However, details about variation range of these inflammatory factors to diagnose cognitive impairment are required to be explored in the near future. Moreover, since inflammation exists widely in chronic decreases, the predictive power of inflammatory markers, referring to the sensitivity and specificity, in the diagnosis and therapy monitoring for cognitive decline in diabetes deserve more concerns.

\section{Comorbid depression as an important risk factor for cognitive decline in diabetes}

Both depression and diabetes are known as important risk factors for cognitive impairment in elderly people [44]. Decreased hippocampal volume was observed in depressed patients when compared with non-depressed patients [45]. However, if the presentence of depression increased the risk of cognitive decline in diabetic patients is unclear. Here, we summarized available studies on the relationship between depression and cognitive impairment in diabetic patients (Table 4). Watari et al. explored the cognitive performance in diabetic patients with depression, revealing that depression negatively correlated with cognitive function [46]. Patients with depression presented worse performance in attention/information processing speed and executive functioning $(P<0.05)$. Similar results were presented by Koekkoek and colleagues, demonstrating 
Table 4: Details about the studies focusing on the relationship between depression and cognitive function in diabetic patients

\begin{tabular}{|c|c|c|c|c|c|c|c|}
\hline Study & Population & Design & Number & $\begin{array}{l}\text { Mean } \\
\text { age }\end{array}$ & $\begin{array}{l}\text { Depression } \\
\text { measure }\end{array}$ & Cognitive measure & $\begin{array}{l}\text { Association with } \\
\text { cognition }\end{array}$ \\
\hline $\begin{array}{l}\text { Johnson et al } \\
{[48]}\end{array}$ & T2DM; US & $\begin{array}{l}\text { Cross-sectional, } \\
\text { observational }\end{array}$ & 2436 & $\begin{array}{l}64.4 \pm \\
10.6\end{array}$ & GDS-30 & $\begin{array}{l}\text { MMSE; WAIS- } \\
\text { III;TMT;WMS-III }\end{array}$ & $\begin{array}{l}\text { Comorbid depression and } \\
\text { age as risk factors for } \\
\text { cognitive impairment }\end{array}$ \\
\hline $\begin{array}{l}\text { Swardfager et } \\
\text { al [52] }\end{array}$ & T2DM; Canada & Cohort study, & 342 & $\begin{array}{l}67 \pm \\
13.5\end{array}$ & CES-D & MoCA; & $\begin{array}{l}\text { Diabetes and depressive } \\
\text { symptoms increases } \\
\text { risk of severe cognitive } \\
\text { impairment }\end{array}$ \\
\hline $\begin{array}{l}\text { Downer et al } \\
\text { [49] }\end{array}$ & T2DM; US & $\begin{array}{l}\text { Retrospective } \\
\text { cohort study }\end{array}$ & 2756 & $\begin{array}{l}73.2 \pm \\
6.1\end{array}$ & CES-D & MMSE; ADL & $\begin{array}{l}\text { Depression correlated } \\
\text { with greater cognitive } \\
\text { decline }\end{array}$ \\
\hline $\begin{array}{l}\text { van Duinkerken } \\
\text { et al [54] }\end{array}$ & $\begin{array}{l}\text { T1DM; } \\
\text { Netherlands }\end{array}$ & $\begin{array}{l}\text { Cross-sectional, } \\
\text { observational }\end{array}$ & 153 & $40 \pm 9.3$ & CES-D & $\begin{array}{l}\text { Memory; } \\
\text { information } \\
\text { processing speed; } \\
\text { executive function; } \\
\text { attention; motor } \\
\text { speed; psychomotor } \\
\text { speed }\end{array}$ & $\begin{array}{l}\text { Increased depressive } \\
\text { symptoms was related to } \\
\text { poorer general cognitive } \\
\text { ability and lower } \\
\text { subgenual cingulate } \\
\text { cortex functional } \\
\text { connectivity }\end{array}$ \\
\hline $\begin{array}{l}\text { Koekkoek et al } \\
\text { [47] }\end{array}$ & $\begin{array}{l}\text { T2DM; } \\
\text { Netherlands }\end{array}$ & $\begin{array}{l}\text { Cross-sectional, } \\
\text { observational }\end{array}$ & 225 & $\begin{array}{l}76.8 \pm \\
5.0\end{array}$ & CES-D & TYM; SAGE & $\begin{array}{l}\text { Depression occurred twice } \\
\text { as often in patients with } \\
\text { cognitive impairment }\end{array}$ \\
\hline $\begin{array}{l}\text { Kadoi et al et } \\
\text { al [53] }\end{array}$ & T2DM; Japan & $\begin{array}{l}\text { Cross-sectional, } \\
\text { observational }\end{array}$ & 90 & $65 \pm 9$ & $\begin{array}{l}\text { 21-item Beck } \\
\text { depression } \\
\text { inventory }\end{array}$ & $\begin{array}{l}\text { MMSE; TMT- } \\
\text { A;TMT-B; digit } \\
\text { span forward; } \\
\text { grooved pegboard }\end{array}$ & $\begin{array}{l}\text { Preoperative depression } \\
\text { as a risk factor for } \\
\text { postoperative short-term } \\
\text { and long-term cognitive } \\
\text { dysfunction }\end{array}$ \\
\hline Watari et al [46] & T2DM; US & $\begin{array}{l}\text { Cross-sectional, } \\
\text { observational }\end{array}$ & 74 & $\begin{array}{l}57.9 \pm \\
11.1\end{array}$ & HAM-D & $\begin{array}{l}\text { MMSE; Attention } \\
\text { and information } \\
\text { processing speed; } \\
\text { TMT-A; WAIS-III }\end{array}$ & $\begin{array}{l}\text { Depression negatively } \\
\text { impacts cognitive } \\
\text { performance }\end{array}$ \\
\hline Guo et al [55] & T2DM; China & Prospective study & 58 & $\begin{array}{l}54.7 \pm \\
7.3\end{array}$ & $\begin{array}{l}\text { MADRS; } \\
\text { HRSD-17 }\end{array}$ & WMS-R; DSM-IV & $\begin{array}{l}\text { Metformin treatment } \\
\text { improved } \\
\text { cognitive function and has } \\
\text { antidepressant behavioural } \\
\text { effects }\end{array}$ \\
\hline $\begin{array}{l}\text { Katon et al } \\
\text { (a) }[50]\end{array}$ & T2DM; US & $\begin{array}{l}\text { Prospective } \\
\text { cohort study }\end{array}$ & 3837 & $\begin{array}{l}63.2 \pm \\
13.2\end{array}$ & PHQ-9 & ICD-9 & $\begin{array}{l}\text { Patients with major } \\
\text { depression with an } \\
\text { increased risk of } \\
\text { development of } \\
\text { dementia }(7.9 \% \text { vs } \\
4.8 \%)\end{array}$ \\
\hline $\begin{array}{l}\text { Katon et al. } \\
\text { (b) }[51]\end{array}$ & T2DM; US & $\begin{array}{l}\text { Prospective } \\
\text { cohort study }\end{array}$ & 19239 & $\begin{array}{l}58.8 \pm \\
10.0\end{array}$ & PHQ-8 & ICD-9 & $\begin{array}{l}\text { Diabetic patients } \\
\text { with depression had } \\
\text { a } 100 \% \text { increased } \\
\text { risk of dementia }\end{array}$ \\
\hline
\end{tabular}

Note: MMSE: Mini-Mental State Examination; TMT: Trail Making Test; MoCA: Montreal cognitive assessment; CES-D: Center for Epidemiological Studies Depression; GDS-30: Geriatric Depression Scale (GDS-30); TYM: Test Your Memory; Self-Administered Gerocognitive Examination; HAM-D: Hamilton Rating Scale for Depression; WMS-R, Wechsler Memory Scale-Revised; MADRS, Montgomery Asberg Depression Rating Scale; MADRS: Montgomery-Asberg Depression Rating Scale; HRSD-1:17-item Hamilton Rating Scale for Depression; DSM-IV: Diagnostic and Statistical Manual of Mental Disorders-Fourth Edition. PHQ-9: Patient Health Questionnaire

that the occurrence of depression increased two-fold risk of cognitive decline in patients with diabetes [47]. Johnson et al. [48] and Downer et al. [49] both detected the impact of depression on diabetes-related cognitive decline in Mexican Americans in large populations. They revealed that comorbid depression in diabetic patients significantly increased the risk of MCI and dementia. A prospective cohort study of 3837 patients explored the influence of comorbid depression on risk of dementia in diabetic patients [50]. After 5-year follow up, the incidence of MCI in diabetic patients was 21.5 per 1,000 person-years, comparing with 11.8 per 1,000 personyears in patients with diabetes alone $(P<0.05)$. These results showed a significant increased risk of dementia 
in depressed diabetics. Two years later, Katon et al. reported their updated data in a larger population $(n=$ $19,239)$, showing a $100 \%$ increased risk of dementia in patients with both diabetes and depression comparing with patients with diabetes [51]. Similar results were also found in diabetic patients after stroke [52], the presence of preoperative depression was an important risk factor for postoperative short-term and long-term cognitive impairment in patients undergoing coronary artery bypass graft surgery [53]. However, the mechanism of depression in diabetic patients is controversial. Studies have shown close relationship between mood disturbances and altered subgenual cingulate cortex (SGC) resting-state functional connectivity. van Duinkerken and his colleagues observed a close correlation between decreased SGC to inferior frontal gyrus and frontal pole connectivity and increased depression symptoms [54]. Thus, comorbid depression was an important risk factor for the development of cognitive impairment in patients with diabetes, suggesting the possibility of beneficial effects of antidepressants treatment on the normalization of cognitive function. To confirm this suspect, Guo et al. performed 6-month intervention of metformin in diabetic patients and found significant improvements in depression symptoms, which was associated with enhanced cognitive function [55]. However, the underlying mechanism of metformin in improving depression and cognition was unestablished. It is also unclear if other hypoglycemic drugs have similar beneficial effects on depression and cognitive impairment in diabetic patients. Future studies should focus on the monitoring of early diagnosis on depression in diabetic patients and explore effective antidepressants treatments to protect diabetic patients from mood disorders.

\section{Association between micro-/macrovascular complications related markers and cognitive decline}

\section{Microvascular complications related markers}

\section{Renal markers}

Diabetes could induce various complications in different organs, especially in kidney, which is called diabetic kidney disease (DKD). Renal function impairment is shown to be related to cognitive decline (Table 5), which increases the mortality and impairs the life quality of patients significantly [56, 57]. Murray et al. [58] explored the correlation between three renal function markers and cognition function, showing that higher level of albumin/ creatinine ratio (ACR) was related to greater decreases in DSS test scores $(P=0.001)$ and RAVLT scores $(P=$ 0.006 ). Similar trend was found between cystatin $C$ and cognitive tests. However, no significant correlation was observed between estimated GFR and ant cognitive tests $(P>0.05)$. Another study from Zhang et al. [59] revealed significant increases of ACR and cystatin $\mathrm{C}$ in diabetic patients with MCI, compared with diabetic patients without MCI. Positive association between increased cystatin C and the risk of cognitive impairment was found in diabetic patients. Moreover, the add on of cystatin $\mathrm{C}$ to traditional risk factors provided a relative high diagnostic value with area under the curve (AUC) as 0.91, suggesting the possibility of cystatin $\mathrm{C}$ as biomarker for cognitive decline in diabetes. In the study by Kawamura [60], correlation between ACR and word recall scores was reported. When estimated GFR decreased, patients presented decreased MMSE and DSS scores. Thus, monitoring renal markers regularly in patients with diabetes not only provide the information about renal function or kidney disease progression, but also shed light on the effective prevention of cognitive decline.

\section{Retinal marker}

Studies have shown close relationship between changes in retinopathy and cognitive impairment (Table 5). Naidu et al. [61] performed their research on 69 newly diagnosed diabetic patients and 69 healthy control, showing positive relationship between venular tortuosity level and cognitive decline $(P=0.013)$. To investigate the changes in vessel diameters, Ryan et al. [23] reported the positive association between retinal arteriolar diameter and metal efficiency. The negative association between retinal venular diameter and metal efficiency was also observed $(P<0.05)$. To explore whether the severity of diabetic retinopathy (DR) is correlated with cognitive impairment, Nwaobi et al. [62] divided 380 diabetic patients into non-DR group $(n=$ 252) and proliferative diabetic retinopathy group (PDR, $n=128$ ), showing that the severity of DR was negatively correlated with cognition function. Interestingly, these results indicated that patients without DR or mild DR presented worse cognitive performance, while patients with PDR exhibited better cognition. Similar results were also reported in animal studies [63]. However, the underlying mechanism for the negative association between DR and cognitive decline was unclear. Since the limited available evidence on DR and cognitive decline, whether the severity of DR can influence the cognitive function remains uncertain. Future studies are required to explore above findings in a larger sample size and longer follow up periods.

\section{Peripheral neuropathy marker}

Few studies have detected the association between peripheral neuropathy and cognitive performance (Table 5). Moreira et al. [64] reported that there was no significant difference in cognitive test scores, such as MMSE, Trail Making Test A and B, between patients with diabetes and patients diabetic peripheral neuropathy (DPN) $(P>$ 0.05). No relationship between DPN assessment scores and cognitive scores was found, indicating no obvious 
Table 5: Details about the studies focusing on the relationship between micro-/macro-vascular disease markers and cognitive function in diabetic patients

\begin{tabular}{|c|c|c|c|c|c|c|c|}
\hline Study & Population & Design & Number & $\begin{array}{l}\text { Mean } \\
\text { age }\end{array}$ & $\begin{array}{l}\text { Vascular } \\
\text { markers }\end{array}$ & Cognitive measure & Association with cognition \\
\hline $\begin{array}{l}\text { Murray et al } \\
{[58]}\end{array}$ & T2DM; UK & $\begin{array}{l}\text { Cross-sectional, } \\
\text { observational }\end{array}$ & 2968 & $\begin{array}{l}62.47 \pm \\
5.7\end{array}$ & $\begin{array}{l}\text { eGFR; ACR; } \\
\text { cystatin C }\end{array}$ & $\begin{array}{l}\text { MMSE; RAVLT; DSST; Stroop } \\
\text { Test }\end{array}$ & $\begin{array}{l}\text { Higher ACR and cystatin C } \\
\text { associated with poor cognitive } \\
\text { function }\end{array}$ \\
\hline $\begin{array}{l}\text { Zhang et al } \\
\text { [59] }\end{array}$ & T2DM; China & $\begin{array}{l}\text { Cross-sectional, } \\
\text { observational }\end{array}$ & 357 & $\begin{array}{l}66.58 \pm \\
9.8\end{array}$ & $\begin{array}{l}\text { eGFR; ACR; } \\
\text { cystatin C }\end{array}$ & $\mathrm{MoCA}$ & $\begin{array}{l}\text { Elevated cystatin } \mathrm{C} \text { associated } \\
\text { with increased risk of MCI }\end{array}$ \\
\hline $\begin{array}{l}\text { Kawamura et } \\
\text { al }[50]\end{array}$ & T2DM; Japan & $\begin{array}{l}\text { Cohort, } \\
\text { observational }\end{array}$ & 67 & $\begin{array}{l}74.60 \pm \\
5.5\end{array}$ & eGFR; ACR; & MMSE; DSST; Stroop Test & $\begin{array}{l}\text { Decreased eGFR correlated with } \\
\text { poor cognitive function }\end{array}$ \\
\hline Naidu et al [61] & T2DM; UK & $\begin{array}{l}\text { Case-control, } \\
\text { observational }\end{array}$ & 137 & $50-70$ & $\begin{array}{l}\text { retinal vessel } \\
\text { calibre, arterio- } \\
\text { venous ratio, } \\
\text { retinal fractal } \\
\text { dimension, retinal } \\
\text { vessel tortuosity }\end{array}$ & TICSM & $\begin{array}{l}\text { Positive correlation between } \\
\text { higher venular tortuosity and } \\
\text { cognitive decline }\end{array}$ \\
\hline Ryan et al [23] & T1DM; US & $\begin{array}{l}\text { Cross-sectional, } \\
\text { observational }\end{array}$ & 244 & $\begin{array}{l}55.2 \pm \\
8.3\end{array}$ & $\begin{array}{l}\text { retinal vessel } \\
\text { diameters } \\
\text { (CRAE, CRVE) }\end{array}$ & $\begin{array}{l}\text { Mental efficiency tests; } \\
\text { nonverbal memory tests; verbal } \\
\text { memory tests }\end{array}$ & $\begin{array}{l}\text { Negative correlation for CRVE; } \\
\text { Positive correlation for CRAE } \\
\text { with cognitive function }\end{array}$ \\
\hline $\begin{array}{l}\text { Nwaobi et al } \\
{[62]}\end{array}$ & T2DM; UK & $\begin{array}{l}\text { Cross-sectional, } \\
\text { observational }\end{array}$ & 380 & $\begin{array}{l}64.8 \pm \\
10.8\end{array}$ & DR severity & $\begin{array}{l}\text { ACE-R; MMSE; } \\
\text { Mini-Cog scores }\end{array}$ & $\begin{array}{l}\text { Negative relationship between } \\
\text { severity of DR and cognition } \\
\text { function }\end{array}$ \\
\hline $\begin{array}{l}\text { Moreira et al et } \\
\text { al [64] }\end{array}$ & T2DM; Brazil & $\begin{array}{l}\text { Cross-sectional, } \\
\text { observational }\end{array}$ & 149 & 65.73 & $\begin{array}{l}\text { HbAlc; } \\
\text { hypoglycemic } \\
\text { events }\end{array}$ & NDS; NSS & No association \\
\hline Bruce et al [67] & $\begin{array}{l}\text { T2DM; } \\
\text { Australia }\end{array}$ & $\begin{array}{l}\text { Cross-sectional, } \\
\text { observational }\end{array}$ & 302 & $\begin{array}{l}75.70 \pm \\
4.6\end{array}$ & $\begin{array}{l}\text { peripheral arterial } \\
\text { disease }\end{array}$ & MMSE; IQCODE & $\begin{array}{l}\text { Peripheral arterial disease as } \\
\text { an independent risk factor for } \\
\text { dementia }\end{array}$ \\
\hline $\begin{array}{l}\text { Feinkohl et al } \\
{[68]}\end{array}$ & T2DM; UK & Cohort study & 832 & $\begin{array}{l}67.69 \pm \\
4.1\end{array}$ & $\begin{array}{l}\text { CV event; cIMT; } \\
\text { ABI; NT-proBNP }\end{array}$ & $\begin{array}{l}\text { MMSE; BVFT; LM; DSC; MR; } \\
\text { MHVS }\end{array}$ & $\begin{array}{l}\text { Positive correlation between } \\
\text { stroke history, ABI, cIMT, } \\
\text { NT-proBNP and accelerated } \\
\text { cognitive impairment }\end{array}$ \\
\hline Chen et al [69] & T2DM; China & Cross-sectional & 157 & $55 \pm 7$ & $\begin{array}{l}\text { HbAlc; age; } \\
\text { gender; lipid } \\
\text { profiles; cIMT; } \\
\text { c-RI; C-peptide }\end{array}$ & $\mathrm{MoCA}$ & $\begin{array}{l}\text { c-RI, C-peptide, hypertension } \\
\text { history as determinants for } \\
\text { MoCA scores }\end{array}$ \\
\hline $\begin{array}{l}\text { Jansen et al } \\
{[70]}\end{array}$ & $\begin{array}{l}\text { T2DM; } \\
\text { Netherlands }\end{array}$ & $\begin{array}{l}\text { Cross-sectional, } \\
\text { observational }\end{array}$ & 80 & $61.85 \pm 8$ & $\begin{array}{l}\text { cerebral blood } \\
\text { flow }\end{array}$ & $\begin{array}{l}\text { MMSE; Cumulative cognition } \\
\text { score }\end{array}$ & No association \\
\hline $\begin{array}{l}\text { Marioni et al } \\
{[71]}\end{array}$ & T2DM; UK & $\begin{array}{l}\text { Cross-sectional, } \\
\text { observational }\end{array}$ & 1066 & $\begin{array}{l}67.9 \pm \\
4.2\end{array}$ & $\begin{array}{l}\text { plasma viscosity; } \\
\text { haematocrit }\end{array}$ & $\begin{array}{l}\text { FACES; DST; LNS; LM;VFT; } \\
\text { TMT; MHVS }\end{array}$ & $\begin{array}{l}\text { Negative correlation for plasma } \\
\text { viscosity; Positive correlation } \\
\text { for haematocrit with cognitive } \\
\text { function }\end{array}$ \\
\hline $\begin{array}{l}\text { Mehrabian et } \\
\text { al [72] }\end{array}$ & $\begin{array}{l}\text { T2DM; } \\
\text { Bulgaria }\end{array}$ & $\begin{array}{l}\text { Cross-sectional, } \\
\text { observational }\end{array}$ & 59 & $56 \pm 6.8$ & $\begin{array}{l}\text { carotid-femoral } \\
\text { pulse wave } \\
\text { velocity }\end{array}$ & $\begin{array}{l}\text { MMSE; FCSRT; BNT; DSS; } \\
\text { TMT; }\end{array}$ & $\begin{array}{l}\text { Positive association between CF- } \\
\text { PWV and cognitive function }\end{array}$ \\
\hline
\end{tabular}

Notes: eGFR: estimated glomerular filtration rate; ACR: albumin/creatinine ratio; MMSE: Mini Mental State Examination; RAVLT: Rey Auditory Verbal Learning Test; DSST: Digit Symbol Substitution Test; TICSM: Telephone Interview for Cognitive Status; CRAE: central retinal arteriolar equivalent; CRVE: central retinal venular equivalent; ACE-R: Addenbrooke's Cognitive Examination-Revised; NDS: Neuropathy Disability Score; NSS: Neuropathy Symptom Score; MCI: mild cognitive impairment; IQCODE: Informant Questionnaire for Cognitive Decline in the Elderly; CV: cardiovascular event history; Cimt: carotid intima-media thickness; ABI: ankle brachial index; NT-proBNP: serum N-terminal probrain natriuretic peptide; BVFT: Borkowski Verbal Fluency Test; LM: The Logical Memory; DSC: The Digit Symbol Coding; MR: Matrix Reasoning; MHVS: Mill Hill Vocabulary Scale; FCSRT: Free and Cued Selective Reminding Test; BNT: Boston Naming Test.

correlation between cognitive impairment and DPN. However, due to the small sample size of available few studies, it is hard to get a confirmed conclusion.

\section{Macrovascular complication related markers}

Besides the close relationship between microvascular diseases and cognitive decline in diabetes, obvious influence of larger vessel changes on cognition function were reported by various studies $[65,66]$ (Table 5). Bruce et al. [67] explored the predictors of cognitive decline in 302 elder diabetic patients, showing that peripheral arterial disease is an independent risk factor for dementia (OR:5.35, $P<0.05$ ). Feinkohl et al. [68] investigated the association between macrovascular disease markers and cognitive decline in 832 diabetic 
patients by detecting clinical parameters, including cardiovascular event history, carotid intima-media thickness (cIMT), ankle brachial index (ABI), and serum $\mathrm{N}$-terminal probrain natriuretic peptide (NT-proBNP). After four follow-up, the stroke history, ABI, cIMT, NTproBNP were found to be correlated with accelerated cognitive impairment, indicating the close relationship among atherosclerosis and cardiac markers and cognitive decline. Study by Chen and his colleague presented carotid resistant index (c-RI) was also important determinants for cognitive decline in diabetic patients [69]. Jansen et al. [70] revealed that low cerebral blood flow (CBF) in cerebral cortex was related to depression in diabetic patients, but not related to cognitive function. Many reasons can contribute to low $\mathrm{CBF}$ in diabetic patients, and factors related to blood rheology might play an important role. To see the impact of blood rheology on cognitive decline, Marioni et al. [71] detected the plasma viscosity and haematocrit in 1,066 patients with diabetes. An inverse association between plasma viscosity and cognitive test scores was observed, while a positive association was observed between haematocrit and cognitive test scores $(P<0.05)$. Mehrabian et al. [72] performed their research on arterial stiffness and cognitive function, revealing that carotid-femoral pulse wave velocity (CF-PWV) was significantly higher in patients with diabetes compared with controls $(P<0.001)$.

Thus, it is valuable to detect both macrovascular and microvascular diseases in diabetic patients. When diabetic patients present macro/microvascular diseases, much more attention should be paid on the evaluation of cognitive function. Especially for diabetic patients with stroke or cardiac event, the prevention and management of cognitive decline shouldn't be ignored.

\section{Association between neurotrophic factors and cognitive decline in diabetes}

Neurotrophic factors can regulate memory-related neuroplasticity and modulate neural cell survival, growth and proliferation [73, 74]. Brain-derived neurotrophic factor (BDNF), as one of the most important neurotrophic factors, is mainly expressed in brain tissue, while it can also be detected in the blood. Zhen et al. [75] explored the association between BDNF and cognitive impairment in 208 diabetic patients and 212 healthy controls. Diabetic patients presented decreased BDNF level, and decreased BDNF level was correlated with poor cognitive function $(P$ $<0.001)$. Similar results were reported by Ortíz et al. [76] in 40 diabetic patients. Thus, low BDNF might be an effective biomarker for diabetes related cognitive impairment.

\section{Association between adipokines and cognitive decline in diabetes}

The incidence of obesity has increased dramatically in the past decades. Studies have shown its intact association with brain dysfunction, cognitive decline and dementia [77]. Adipokines, as hormones secreted from adipose tissue, are considered to be important mediators for obesity-related cognitive impairment [78]. Study by Casares et al. [79] investigated that lower adiponectin was related to impaired glucose metabolism and decreased gray matter volume in diabetic patients $(P<0.001)$. Consistent results were demonstrated by Ciebiada et al. [40], who revealed decreased adiponectin level in MCI patients. Beyond that, Ciebiada et al. found increased leptin level in MCI group, which is another adipokine released by adipose tissue. Labad et al. [80] illustrated an inverse association between leptin level and cognitive performance in 1,057 diabetic patients, indicating that higher fasting leptin correlated with poorer cognitive test scores $(P<0.02)$. Thus, adiopkines can be valuable markers for the cognitive impairment, especially for adiponectin and leptin levels. However, the specificity and sensitivity of these markers were unknown, when compared with traditional markers.

\section{Association between Tau protein and $A \beta_{42}$ and cognitive decline in diabetes}

Close relationship between diabetes and Alzheimer's disease $(\mathrm{AD})$ has been reported in recent years [3, 81]. $\beta$-amyloid $(\mathrm{A} \beta$ ) deposition and Tau hyperphosphorylation are known as classical pathogenic factors of AD [82, 83]. Ouwens et al. detected AD-related markers in cerebrospinal fluid (CSF) on 37 patients with T1DM and 15 healthy controls. Higher level of pTau and A $\beta 42$ in CSF were found in T1DM patients $(P<0.05)$. Moreover, increased Tau protein was found to be correlated with declined white matter in right inferior fronto-occipital tract $(P=0.002)$. In study by Moran et al. [84], patients with T2DM showed significantly higher total Tau and pTau levels in $\mathrm{CSF}(P=0.04, P=0.02$, respectively). Thus, diabetes can induce the classical pathogenesis of AD, which is reflected by increased $A \beta 42$, Tau and pTau levels. These markers could provide remarkable clues in the development of diabetes-associated cognitive impairment and $\mathrm{AD}$, which can also be used for the assessment of cognitive function in diabetes.

\section{Neuroimaging as efficient tools to detect cognitive decline in diabetes}

\section{MRI alterations of cognitive decline in diabetes}

Lower brain volume and brain atrophy are considered as features of many neurodegenerative diseases. Studies have shown diabetes-associated cognitive decline could induce structural lesions, which can be reflected by neuroimaging tools [85-87]. Thus, exploring altered structural pattern in diabetic patients with cognitive decline might provide possible mechanisms of neurodegenerative process in diabetes. However, 
Table 6: Details about the studies focusing on the relationship between genetic factors and cognitive function in diabetic patients

\begin{tabular}{|c|c|c|c|c|c|c|c|}
\hline Study & Population & Design & Number & Mean age & Genetic factors & $\begin{array}{l}\text { Cognitive } \\
\text { measure }\end{array}$ & $\begin{array}{l}\text { Association with } \\
\text { cognition }\end{array}$ \\
\hline $\begin{array}{l}\text { Guerrero- } \\
\text { Berroa et } \\
\text { al [108] }\end{array}$ & T2DM; Israel & $\begin{array}{l}\text { Cross- } \\
\text { sectional, } \\
\text { observational }\end{array}$ & 793 & $72.8 \pm 4.5$ & Haptoglobin 1-1 & $\begin{array}{l}\text { MMSE; } \\
\text { CDR }\end{array}$ & $\begin{array}{l}\text { HP 1-1 carriers } \\
\text { associated with } \\
\text { higher risk of } \\
\text { cognitive decline }\end{array}$ \\
\hline $\begin{array}{l}\text { Wang et al } \\
\text { et al [24] }\end{array}$ & $\begin{array}{l}\text { T2DM; } \\
\text { China }\end{array}$ & $\begin{array}{l}\text { Cross- } \\
\text { sectional, } \\
\text { observational }\end{array}$ & 167 & $\begin{array}{l}60.15 \pm \\
7.47\end{array}$ & RAGE Gly82Ser & $\begin{array}{l}\text { MoCA; } \\
\text { DST; } \\
\text { TMT; } \\
\text { CDR; } \\
\text { CDT; ST; } \\
\text { VFT }\end{array}$ & No association \\
\hline $\begin{array}{l}\text { Tian et al } \\
{[111]}\end{array}$ & $\begin{array}{l}\text { T2DM; } \\
\text { China }\end{array}$ & $\begin{array}{l}\text { Cross- } \\
\text { sectional, } \\
\text { observational }\end{array}$ & 210 & $60.19 \pm 0.6$ & $\begin{array}{l}\text { I/D gene of ACE; } \\
\text { ACE level and } \\
\text { activity }\end{array}$ & $\begin{array}{l}\text { MoCA; } \\
\text { DST; VFT; } \\
\text { CDT; ST; } \\
\text { TMT; } \\
\text { SCWT; } \\
\text { AVLT; }\end{array}$ & $\begin{array}{l}\text { Increased ACE } \\
\text { level and activity } \\
\text { in cognitive } \\
\text { decline; No } \\
\text { association for } \\
\text { ACE I/D gene and } \\
\text { cognition }\end{array}$ \\
\hline $\begin{array}{l}\text { Xu et al } \\
{[113]}\end{array}$ & $\begin{array}{l}\text { T2DM; } \\
\text { China }\end{array}$ & $\begin{array}{l}\text { Cross- } \\
\text { sectional, } \\
\text { observational }\end{array}$ & 694 & $\begin{array}{l}74.92 \pm \\
6.44\end{array}$ & $\begin{array}{l}\text { ApoE } \varepsilon 2 ; \text { ApoE } \\
\varepsilon 3 ; \text { ApoE } \varepsilon 4 \text { allele }\end{array}$ & $\begin{array}{l}\text { MMSE; } \\
\text { CDR }\end{array}$ & $\begin{array}{l}\text { diagnostic } \\
\text { accuracy of ApoE } \\
\varepsilon 4 \text { gene for MCI: } \\
0.72\end{array}$ \\
\hline $\begin{array}{l}\text { Jacobson } \\
\text { et al [114] }\end{array}$ & T1DM; US & $\begin{array}{l}\text { Retrospective, } \\
\text { observational }\end{array}$ & 1093 & $45.7 \pm 6.8$ & $\begin{array}{l}\text { ApoE (rs7412; } \\
\text { rs429358); ACE } \\
\text { (rs4340) }\end{array}$ & $\begin{array}{l}\text { WAIS; } \\
\text { DVT; } \\
\text { FAS; TMT }\end{array}$ & No association \\
\hline
\end{tabular}

Notes: DST: digit symbol test; TMT: Trail Making Test-Part B; VFT: Verbal Fluency Test; MMSE: Mini-Mental State Examination; MCI: mild cognitive impairment; AVLT: Auditory Verbal Learning Test; CDR: Clinical Dementia Rating; SCWT: Stroop Color Words Test; FAS: Verbal Fluency Test; WAIS: Wechsler Adult Intelligence Scale; DVT: Digit Vigilance Test; CDT: the clock drawing test; ST: similarities test.

limited studies investigated the brain changes in diabetic patients with cognitive impairment. Moran et al. [88] found positive associations between diabetes and cerebral infarcts, lower gray as well as white matter volumes $(P<0.05)$. Female were more susceptive to cerebral complications, when compared with male [89]. Hayashi et al. revealed that cognitive impairment was associated with hippocampal atrophy, but not the whole brain atrophy in 61 Japanese diabetic patients [90]. Zhang et al. [91] investigated the brain changes in diabetic patients with and without MCI. Positive relationship between atrophy of middle temporal gyrus and increased risk of MCI was observed. Besides gray matter volume, Manschot et al. found impaired cognitive function correlated with white matter lesions, cortical atrophy and infarcts $(P<0.05)$ [92]. Moreover, periventricular hyperintensities was reported to be associated with motor speed [93]. Thus, MRI can reflect brain structural changes in patients with diabetes and cognitive decline, although specific affected regions caused by the diabetes were not consistent.

\section{fMRI alterations of cognitive decline in diabetes}

Functional MRI (fMRI) provides a good platform to explore the alterations of brain function in patients with cognitive decline in vivo $[94,95]$. Studies have shown that functional changes might exist before the appearance of brain structure alterations. Thus, fMRI could be a valuable tool to detect early markers of diabetes-related cognitive decline. Default mode network (DMN) is a region in charge of cognitive tasks. Marder et al [96] showed impaired deactivation DMN regions during recognition task in diabetic patients, which was correlated with peripheral plasma glucose level. Chen's study presented similar results in the DMN regions (including right precuneus and the middle temporal gyrus) during memory tasks [97]. They concluded that the anterior-posterior connectivity dysfunction in diabetes might contributed to cognitive impairment. In diabetic patients with MCI, Yang et al. [98] found disturbed intranetwork and internetwork functional connectivity DMN region, $\mathrm{CON}$ region, right 
insula and posterior cerebellum. These dysfunctions were positively correlated with $\mathrm{HbA} 1 \mathrm{c}$ and DM duration, indicating the key role of hyperglycemia in the process of cognitive decline. Zeng et al. demonstrated consistent results in 28 diabetic patients and found dysfunctional network was related to poorer MoCA scores [99]. Thus, the network organization and functional connectivity in some brain regions could be affected in patients with diabetes, which can be used for the evaluation and diagnosis of cognitive decline.

\section{MRS alterations of cognitive decline in diabetes}

Brain, as one of the target organ affected by diabetes, has shown metabolic dysfunction in various studies $[100,101]$. To explore the altered brain metabolites is of great value in detecting cognitive decline at early stage. Magnetic resonance spectroscopy (MRS), as a neuroimaging method, can detect the alterations of neurochemicals related to metabolism and energetics in vivo [102]. Wang et al. [103] performed their study in 188 T2DM patients and observed altered brain metabolites in hippocampus rather than frontal lobe. Increased myoinositol and creatine levels in hippocampus were correlated with poor cognitive test scores. In Lyoo's study [104], 123 T1DM patients presented significantly higher glutamate, glutamate and GABA levels in prefrontal area when compared with healthy controls. An inverse association was found between these metabolites and cognitive function. However, inconsistent results were reported by Tiehuis et al. [105], they showed there was no relationship between cognitive function and brain metabolites in white matter of patients with diabetes. Based on limited evidence, we could believe there were metabolic dysfunctions in diabetic brain, and these changes were closely related to the appearance of cognitive decline in diabetes. However, the valuable and specific metabolites as biomarkers for cognitive decline in diabetes were not found.

\section{Genetic factors related to cognitive decline in diabetes}

Findings associated with genetic factors for cognitive decline is of great interest for clinicians and researchers. However, available evidence presented controversial results (Table 6). Haemoglobinbinding protein can protect cells from oxidative damage, which is produced from haptoglobin (Hp) gene [106]. Studies have shown that Hp gene presented obvious downregulation in MCI patients when compared with controls [107]. Berroa et al. revealed that HP 1-1 carriers showed a stronger relationship between $\mathrm{HbA} 1 \mathrm{c}$ and impaired cognitive performance $(P<0.01)$ [108]. These indicated HP 1-1 carriers hold a higher risk for cognitive decline. RAGE gene is one of the important genes in diabetic complications, Gly82Ser polymorphism of RAGE gene was reported to play an important role in AD [109]. Wang et al. [24] found RAGE Gly82Ser carriers with lower RAGE concentration than non-carriers in MCI patients $(P=0.003)$. But no significant association was reported between cognitive test scores and $82 \mathrm{Gly} / \mathrm{Ser}$ genotype $(P>0.05)$. Angiotensin-converting enzyme (ACE) is one of the key genes in RAS system [110]. Studies have shown that Ang II was related to AD in elder patients. Tian et al. [111] analyzed different I/D single-nucleotide polymorphisms of ACE gene in T2DM patients $(n=210)$. Patients with MCI presented higher ACE level and ACE activity. However, these was no change in the genotype of ACE I/D polymorphism in these patients. The APOE gene is known to play a key role in lipid metabolism in brain tissue, which is closely related to cognitive function [112]. Xu et al. [113] explored the biomarkers for the diagnosis of MCI in diabetic patients $(n=694)$. In their study, older age, ApoE $\varepsilon 4$ allele, higher olfactory score and higher rGSK-3 $\beta$ (ratio of total GSK-3 $\beta$ to Ser9phosphorylated GSK-3 $\beta$ ) were potential biomarkers for MCI in diabetic patients, with the accuracy as 0.76 , $0.72,0.66,0.79$, respectively. To improve the diagnostic accuracy, the combined four biomarkers showed the diagnostic accuracy of $83 \%$. Diabetic patients with MCI presented more susceptibility to ApoE $\varepsilon 4$ gene when compared with diabetic patients without MCI. Besides, six ApoE genotypes including $\varepsilon 2 \varepsilon 2, \varepsilon 3 \varepsilon 3, \varepsilon 4 \varepsilon 4, \varepsilon 2 \varepsilon 3, \varepsilon 2 \varepsilon 4$, and $\varepsilon 3 \varepsilon 4$ were detected in included patients, showing that the prevalence of $\varepsilon 3 \varepsilon 4$ genotype was higher while $\varepsilon 3 \varepsilon 3$ was lower in T2DM-MCI group. However, other ApoE genotypes presented no obvious difference in T2DM-MCI group and T2DM group. Thus, aging, activation of GSK$3 \beta$, ApoE $\varepsilon 4$ expression and increased olfactory score are diagnostic for MCI in T2DM patients, and combination of these biomarkers can improve the diagnostic accuracy. However, inconsistent results were reported by Jacobson et al. [114]. They reported that ACE gene and ApoE \&4 gene were not related with increased risk of cognitive impairment in T1DM patients during 18-year follow up. Although current evidence is limited, consistent results were reported in different studies that the genetic factors influencing the risk of cognitive decline in patients with diabetes. Future studies should validate above findings in a larger amount of population, and the accuracy measurements of each parameter or biomarker are highly recommended.

\section{CONCLUSIONS}

In conclusion, we summarized available evidences on risk factors for cognitive decline in diabetic patients. The biomarkers or risk factors of cognitive decline in diabetic patients could be classified into the following three aspects: serum molecules or relevant complications, functional or metabolic changes by neuroimaging tools, 
and genetic variants. Specifically, factors related to poor glucose metabolism, insulin resistance, inflammation, comorbid depression, micro-/macrovascular complications, adipokines, neurotrophic molecules and Tau protein presented significant changes in diabetic patients with cognitive decline. Neuroimaging platform could provide more clues on the structural, functional and metabolic changes during the cognitive decline progression of diabetic patients. Genetic factors related to cognitive decline showed inconsistency based on the limited studies. Future studies should validate above findings in a larger population in order to find valuable, sensitive and specific biomarkers on early diagnosis for cognitive decline in diabetic patients.

\section{Author contributions}

Xue Zhao and Guixia Wang: designed this review; Xue Zhao and Qing Han: conducted the paper selection; Lin Sun, Xiaokun Gang and You Lv: performed the statistical analysis and data extraction; Xue Zhao and Guixia Wang: wrote the manuscript. All authors: read and approved the final manuscript. Xue Zhao and Qing Han contribute equally to this work.

\section{CONFLICTS OF INTEREST}

No conflicts of interest was declared.

\section{FUNDING}

This work was supported by grants (belonging to Guixia Wang) from the National Natural Science Fund of China (81670732). It was also supported by grants (belonging to Xue Zhao) from Graduate Innovation Fund of Jilin University (2016042).

\section{REFERENCES}

1. Schimming C, Luo X, Zhang C, Sano M. Cognitive performance of older adults in a specialized diabetes clinic. J Diabetes. 2016. https://doi.org/10.1111/1753-0407.12503.

2. Cheng G, Huang C, Deng H, Wang H. Diabetes as a risk factor for dementia and mild cognitive impairment: a meta-analysis of longitudinal studies. Intern Med J. 2012; 42:484-91.

3. Biessels GJ, Staekenborg S, Brunner E, Brayne C, Scheltens P. Risk of dementia in diabetes mellitus: a systematic review. Lancet Neurology. 2006; 5:64-74.

4. Geijselaers SLC, Sep SJS, Stehouwer CDA, Biessels GJ. Glucose regulation, cognition, and brain MRI in type 2 diabetes: a systematic review. Lancet Diabetes \& Endocrinology. 2015; 3:75-89.

5. Lu FP, Lin KP, Kuo HK. Diabetes and the risk of multisystem aging phenotypes: a systematic review and metaanalysis. Plos One. 2009; 4:e4144.
6. Willette AA, Bendlin BB, Starks EJ, Birdsill AC, Johnson SC, Christian BT, Okonkwo OC, La RA, Hermann BP, Koscik RL. Association of Insulin Resistance With Cerebral Glucose Uptake in Late Middle-Aged Adults at Risk for Alzheimer Disease. Jama Neurology. 2015; 72:1013-20.

7. Moran C, Phan TG, Chen J, Blizzard L, Beare R, Venn A, Munch G, Wood AG, Forbes J, Greenaway TM. Brain Atrophy in Type 2 Diabetes: Regional distribution and influence on cognition. Diabetes Care. 2013; 36:4036-42.

8. Koekkoek PS, Kappelle LJ, van den Berg E, Rutten GE, Biessels GJ. Cognitive function in patients with diabetes mellitus: guidance for daily care. Lancet Neurology. 2015; 14:329-40.

9. Jagielski AC, Jiang CQ, Xu L, Taheri S, Zhang WS, Cheng KK, Lam TH, Thomas GN. Glycaemia is associated with cognitive impairment in older adults: the Guangzhou Biobank Cohort Study. Age Ageing. 2015; 44:65-71.

10. Singhmanoux A, Dugravot A, Brunner E, Kumari M, Shipley M, Elbaz A, Kivimaki M. Interleukin-6 and C-reactive protein as predictors of cognitive decline in late midlife. Neurology. 2014; 83:486-93.

11. Mielke MM, Rosenberg PB, Tschanz J, Cook L, Corcoran C, Hayden KM, Norton M, Rabins PV, Green RC, Welshbohmer KA. Vascular factors predict rate of progression in Alzheimer disease. Neurology. 2007; 69:1850.

12. Brundel M, Kappelle LJ, Biessels GJ. Brain imaging in type 2 diabetes. Eur Neuropsychopharmacol. 2014; 24:1967-81.

13. Zhou Y, Fang R, Liu LH, Chen SD, Tang HD. Clinical Characteristics for the Relationship between Type-2 Diabetes Mellitus and Cognitive Impairment: A CrossSectional Study. Aging Dis. 2015; 6:236-44.

14. Moulton CD, Stewart R, Amiel SA, Laake JP, Ismail K. Factors associated with cognitive impairment in patients with newly diagnosed type 2 diabetes: a cross-sectional study. Aging Ment Health. 2016; 20:840-7.

15. Bruce DG, Davis WA, Starkstein SE, Davis TM. Midlife predictors of cognitive impairment and dementia in type 2 diabetes mellitus: the Fremantle Diabetes Study. J Alzheimers Dis. 2014; 42 Suppl 3: S63-70.

16. Lee YJ, Kang HM, Kim NK, Yang JY, Noh JH, Ko KS, Rhee BD, Kim DJ. Factors associated for mild cognitive impairment in older korean adults with type 2 diabetes mellitus. Diabetes Metab J. 2014; 38:150-7.

17. Ma L, Li Y. Cognitive function and insulin resistance in elderly patients with type 2 diabetes. Neurol Res. 2017; 39:259-63.

18. Kinoshita T, Shimoda M, Sanada J, Fushimi Y, Hirata Y, Irie S, Tanabe A, Obata A, Kimura T, Hirukawa H, Kohara K, Tatsumi F, Kamei S, et al. Association of GA/HbAlc ratio and cognitive impairment in subjects with type 2 diabetes mellitus. J Diabetes Complications. 2016; 30:1452-5.

19. Cui X, Abduljalil A, Manor BD, Peng CK, Novak V. Multiscale glycemic variability: a link to gray matter atrophy 
and cognitive decline in type 2 diabetes. PLoS One. 2014; 9:e86284

20. Ryan CM, Geckle MO, Orchard TJ. Cognitive efficiency declines over time in adults with Type 1 diabetes: effects of micro- and macrovascular complications. Diabetologia. 2003; 46:940-8.

21. Bree AJ, Puente EC, Daphnaiken D, Fisher SJ. Diabetes increases brain damage caused by severe hypoglycemia. American Journal of Physiology Endocrinology \& Metabolism. 2009; 297:E194.

22. Chin SO, Rhee SY, Chon S, Baik SH, Park Y, Nam MS, Lee KW, Chun KH, Woo JT, Kim YS. Hypoglycemia is associated with dementia in elderly patients with type 2 diabetes mellitus: An analysis based on the Korea National Diabetes Program Cohort. Diabetes Res Clin Pract. 2016; 122:54-61.

23. Ryan CM, Klein BE, Lee KE, Cruickshanks KJ, Klein R. Associations between recent severe hypoglycemia, retinal vessel diameters, and cognition in adults with type 1 diabetes. J Diabetes Complications. 2016; 30:1513-8.

24. Wang P, Huang R, Lu S, Xia W, Cai R, Sun H, Wang S. RAGE, AGEs in Mild Cognitive Impairment of Diabetic Patients: A Cross-Sectional Study. PLoS One. 2016; 11:e0145521.

25. Gorska-Ciebiada M, Saryusz-Wolska M, Borkowska A, Ciebiada M, Loba J. C-Reactive Protein, Advanced Glycation End Products, and Their Receptor in Type 2 Diabetic, Elderly Patients with Mild Cognitive Impairment. Front Aging Neurosci. 2015; 7:209.

26. Ma L, Wang J, Li Y. Insulin resistance and cognitive dysfunction. Clin Chim Acta. 2015; 444:18-23.

27. Hishikawa N, Yamashita T, Deguchi K, Wada J, Shikata $\mathrm{K}$, Makino H, Abe K. Cognitive and affective functions in diabetic patients associated with diabetes-related factors, white matter abnormality and aging. Eur J Neurol. 2015; 22:313-21.

28. Zhong Y, Miao Y, Jia WP, Yan H, Wang BY. Hyperinsulinemia,Insulin Resistance and Cognitive Decline in Older Cohort. Biomedical and Environmental Sciences. 2012; 25:8-14.

29. Umegaki H, Makino T, Uemura K, Shimada H, Hayashi T, Cheng XW, Kuzuya M. The Associations among Insulin Resistance, Hyperglycemia, Physical Performance, Diabetes Mellitus, and Cognitive Function in Relatively Healthy Older Adults with Subtle Cognitive Dysfunction. Front Aging Neurosci. 2017; 9:72.

30. Ekblad LL, Rinne JO, Puukka PJ, Laine HK, Ahtiluoto SE, Sulkava RO, Viitanen MH, Jula AM. Insulin resistance is associated with poorer verbal fluency performance in women. Diabetologia. 2015; 58:2545-53.

31. Willette AA, Modanlo N, Kapogiannis D. Insulin resistance predicts medial temporal hypermetabolism in mild cognitive impairment conversion to Alzheimer disease. Diabetes. 2015; 64:1933-40.
32. Neergaard JS, Dragsbæk K, Christiansen C, Nielsen HB, Brix S, Karsdal MA, Henriksen K. Metabolic Syndrome, Insulin Resistance and Cognitive Dysfunction: Does your metabolic profile affect your brain? Diabetes. 2017; 66:1957-63.

33. Ng TP, Feng L, Nyunt MS, Feng L, Gao Q, Lim ML, Collinson SL, Chong MS, Lim WS, Lee TS, Yap P, Yap KB. Metabolic Syndrome and the Risk of Mild Cognitive Impairment and Progression to Dementia: Follow-up of the Singapore Longitudinal Ageing Study Cohort. JAMA Neurol. 2016; 73:456-63.

34. Del Brutto OH, Mera RM, Zambrano M. Metabolic syndrome correlates poorly with cognitive performance in stroke-free community-dwelling older adults: a populationbased, cross-sectional study in rural Ecuador. Aging Clin Exp Res. 2016; 28:321-5.

35. Geijselaers SLC, Sep SJS, Schram MT, van Boxtel MPJ, Henry RMA, Verhey FRJ, Kroon AA, Schaper NC, Dagnelie PC, van der Kallen CJH, Stehouwer CDA, Biessels GJ. Insulin resistance and cognitive performance in type 2 diabetes - The Maastricht study. J Diabetes Complications. 2017; 31:824-30.

36. Feng B, Hu P, Lu SJ, Wang R, Du YF. Effects of APP 5-mer peptide analogue P165 on the synaptic proteins and insulin signal transduction proteins. International Journal of Clinical \& Experimental Medicine. 2014; 7:549.

37. Rogers J, Mastroeni D, Leonard B, Joyce J, Grover A. Neuroinflammation in Alzheimer's disease and Parkinson's disease: are microglia pathogenic in either disorder? International Review of Neurobiology. 2007; 82:235-46.

38. Marioni RE, Strachan MW, Reynolds RM, Lowe GD, Mitchell RJ, Fowkes FG, Frier BM, Lee AJ, Butcher I, Rumley A, Murray GD, Deary IJ, Price JF. Association between raised inflammatory markers and cognitive decline in elderly people with type 2 diabetes: the Edinburgh Type 2 Diabetes Study. Diabetes. 2010; 59:710-3.

39. Gorska-Ciebiada M, Saryusz-Wolska M, Borkowska A, Ciebiada M, Loba J. Serum levels of inflammatory markers in depressed elderly patients with diabetes and mild cognitive impairment. PLoS One. 2015; 10:e0120433.

40. Gorska-Ciebiada M, Saryusz-Wolska M, Borkowska A, Ciebiada M, Loba J. Adiponectin, leptin and IL-1 beta in elderly diabetic patients with mild cognitive impairment. Metab Brain Dis. 2016; 31:257-66.

41. Gorska-Ciebiada M, Saryusz-Wolska M, Borkowska A, Ciebiada M, Loba J. Serum Soluble Adhesion Molecules and Markers of Systemic Inflammation in Elderly Diabetic Patients with Mild Cognitive Impairment and Depressive Symptoms. Biomed Res Int. 2015; 2015:826180.

42. Chung CC, Pimentel D, Jor'Dan AJ, Hao Y, Milberg W, Novak V. Inflammation-associated declines in cerebral vasoreactivity and cognition in type 2 diabetes. Neurology. 2015; 85:450-8.

43. Lavielle $\mathrm{P}$, Talavera JO, Reynoso N, González M, Gómezdíaz RA, Cruz $\mathrm{M}$, Vázquez $\mathrm{F}$, Wacher $\mathrm{NH}$. 
Prevalence of Cognitive Impairment in Recently Diagnosed Type 2 Diabetes Patients: Are Chronic Inflammatory Diseases Responsible for Cognitive Decline? Plos One. 2015; 10:e141325.

44. Strachan MW, Reynolds RM, Marioni RE, Price JF. Cognitive function, dementia and type 2 diabetes mellitus in the elderly. Nature Reviews Endocrinology. 2011; 7:108.

45. Campbell S, Marriott M, Nahmias C, Macqueen GM. Lower hippocampal volume in patients suffering from depression: a meta-analysis. American Journal of Psychiatry. 2004; 161:598-607.

46. Watari K, Letamendi A, Elderkin-Thompson V, Haroon E, Miller J, Darwin C, Kumar A. Cognitive function in adults with type 2 diabetes and major depression. Arch Clin Neuropsychol. 2006; 21:787-96.

47. Koekkoek PS, Biessels GJ, Kooistra M, Janssen J, Kappelle JL, Rutten GE, Cog-ID Study Group. Undiagnosed cognitive impairment, health status and depressive symptoms in patients with type 2 diabetes. J Diabetes Complications. 2015; 29:1217-22.

48. Johnson LA, Gamboa A, Vintimilla R, Cheatwood AJ, Grant A, Trivedi A, Edwards M, Hall JR, O'Bryant SE. Comorbid Depression and Diabetes as a Risk for Mild Cognitive Impairment and Alzheimer's Disease in Elderly Mexican Americans. J Alzheimers Dis. 2015; 47:129-36.

49. Downer B, Vickers BN, Al Snih S, Raji M, Markides KS. Effects of Comorbid Depression and Diabetes Mellitus on Cognitive Decline in Older Mexican Americans. J Am Geriatr Soc. 2016; 64:109-17.

50. Katon WJ, Lin EH, Williams LH, Ciechanowski P, Heckbert SR, Ludman E, Rutter C, Crane PK, Oliver M, Von Korff M. Comorbid depression is associated with an increased risk of dementia diagnosis in patients with diabetes: a prospective cohort study. J Gen Intern Med. 2010; 25:423-9.

51. Katon W, Lyles CR, Parker MM, Karter AJ, Huang ES, Whitmer RA. Association of depression with increased risk of dementia in patients with type 2 diabetes: the Diabetes and Aging Study. Arch Gen Psychiatry. 2012; 69:410-7.

52. Swardfager W, MacIntosh BJ. Depression, Type 2 Diabetes, and Poststroke Cognitive Impairment. Neurorehabil Neural Repair. 2017; 31:48-55.

53. Kadoi Y, Kawauchi C, Ide M, Kuroda M, Takahashi K, Saito S, Fujita N, Mizutani A. Preoperative depression is a risk factor for postoperative short-term and long-term cognitive dysfunction in patients with diabetes mellitus. Journal of Anesthesia. 2011; 25:10-7.

54. van Duinkerken E, Ryan CM, Schoonheim MM, Barkhof F, Klein M, Moll AC, Diamant M, IJzerman RG, Snoek FJ. Subgenual Cingulate Cortex Functional Connectivity in Relation to Depressive Symptoms and Cognitive Functioning in Type 1 Diabetes Mellitus Patients. Psychosom Med. 2016; 78:740-9.

55. Guo M, Mi J, Jiang QM, Xu JM, Tang YY, Tian G, Wang B. Metformin may produce antidepressant effects through improvement of cognitive function among depressed patients with diabetes mellitus. Clin Exp Pharmacol Physiol. 2014; 41:650-6.

56. Tamura MK, Wadley V, Yaffe K, Mcclure LA, Howard G, Go R, Allman RM, Warnock DG, Mcclellan W. Kidney Function and Cognitive Impairment in US Adults: The Reasons for Geographic and Racial Differences in Stroke (REGARDS) Study. American Journal of Kidney Diseases. 2008; 52:227-34.

57. Buchman AS, Tanne D, Boyle PA, Shah RC, Leurgans SE, Bennett DA. Kidney function is associated with the rate of cognitive decline in the elderly. Neurology. 2009; 73:920-7.

58. Murray AM, Barzilay JI, Lovato JF, Williamson JD, Miller ME, Marcovina S, Launer LJ. Biomarkers of renal function and cognitive impairment in patients with diabetes. Diabetes Care. 2011; 34:1827-32.

59. Zhang JB, Geng N, Li ZG, Qiao HJ, Sun HR, Li F. Biomarkers of Renal Function in Type 2 Diabetic Patients with Cognitive Impairment. Neuroscience Letters. 2016; 610:19-23.

60. Kawamura $\mathrm{T}$, Umemura $\mathrm{T}$, Umegaki $\mathrm{H}$, Imamine $\mathrm{R}$, Kawano N, Tanaka C, Kawai M, Minatoguchi M, Kusama M, Kouchi Y, Watarai A, Kanai A, Nakashima E, et al. Effect of renal impairment on cognitive function during a 3 -year follow up in elderly patients with type 2 diabetes: Association with microinflammation. J Diabetes Investig. 2014; 5:597-605.

61. Naidu VV, Ismail K, Amiel S, Kohli R, Crosby-Nwaobi R, Sivaprasad S, Stewart R. Associations between Retinal Markers of Microvascular Disease and Cognitive Impairment in Newly Diagnosed Type 2 Diabetes Mellitus: A Case Control Study. PLoS One. 2016; 11:e0147160.

62. Crosby-Nwaobi RR, Sivaprasad S, Amiel S, Forbes A. The relationship between diabetic retinopathy and cognitive impairment. Diabetes Care. 2013; 36:3177-86.

63. Kodl CT, Seaquist ER. Cognitive dysfunction and diabetes mellitus. Endocrine Reviews. 2008; 29:494-511.

64. Moreira RO, Soldera AL, Cury B, Meireles C, Kupfer R. Is cognitive impairment associated with the presence and severity of peripheral neuropathy in patients with type 2 diabetes mellitus? Diabetol Metab Syndr. 2015; 7:51.

65. Rafnsson SB, Deary IJ, Smith FB, Whiteman MC, Fowkes FG. Cardiovascular diseases and decline in cognitive function in an elderly community population: the Edinburgh Artery Study. Psychosomatic Medicine. 2007; 69:425-34.

66. Singh-Manoux A, Britton AR, Marmot M. Vascular Disease and Cognitive Function: Evidence from the Whitehall II Study. Journal of the American Geriatrics Society. 2003; 51:1445-50.

67. Bruce DG, Davis WA, Casey GP, Starkstein SE, Clarnette RM, Foster JK, Almeida OP, Davis TM. Predictors of cognitive impairment and dementia in older people with diabetes. Diabetologia. 2008; 51:241-8.

68. Feinkohl I, Keller M, Robertson CM, Morling JR, Williamson RM, Nee LD, Mclachlan S, Sattar N, Welsh P, Reynolds RM. Clinical and subclinical macrovascular 
disease as predictors of cognitive decline in older patients with type 2 diabetes: the Edinburgh Type 2 Diabetes Study. Diabetes Care. 2013; 36:2779-86.

69. Chen RH, Jiang XZ, Zhao XH, Qin YL, Gu Z, Gu PL, Zhou B, Zhu ZH, Xu LY, Zou YF. Risk factors of mild cognitive impairment in middle aged patients with type 2 diabetes: A cross-section study. Annales d'Endocrinologie. 2012; 73:208-12.

70. Jansen JF, van Bussel FC, van de Haar HJ, van Osch MJ, Hofman PA, van Boxtel MP, van Oostenbrugge RJ, Schram MT, Stehouwer CD, Wildberger JE, Backes WH. Cerebral blood flow, blood supply, and cognition in Type 2 Diabetes Mellitus. Sci Rep. 2016; 6:10.

71. Marioni RE, Deary IJ, Strachan MW, Lowe GD, Rumley A, Murray GD, Price JF. Blood rheology and cognition in the Edinburgh Type 2 Diabetes Study. Age Ageing. 2010; 39:354-9.

72. Mehrabian S, Raycheva M, Gateva A, Todorova G, Angelova P, Traykova M, Stankova T, Kamenov Z, Traykov L. Cognitive dysfunction profile and arterial stiffness in type 2 diabetes. J Neurol Sci. 2012; 322:152-6.

73. Meier P. Neurotrophins as synaptic modulators. Nature Reviews Neuroscience. 2001; 2:24-32.

74. Egan MF, Kojima M, Callicott JH, Goldberg TE, Kolachana BS, Bertolino A, Zaitsev E, Gold B, Goldman D, Dean M. The BDNF val66met polymorphism affects activitydependent secretion of BDNF and human memory and hippocampal function. Cell. 2003; 112:257-69.

75. Zhen YF, Zhang J, Liu XY, Fang H, Tian LB, Zhou DH, Kosten TR, Zhang XY. Low BDNF is associated with cognitive deficits in patients with type 2 diabetes. Psychopharmacology (Berl). 2013; 227:93-100.

76. Murillo Ortiz B, Ramirez Emiliano J, Ramos-Rodriguez E, Martinez-Garza S, Macias-Cervantes H, Solorio-Meza S, Pereyra-Nobara TA. Brain-derived neurotrophic factor plasma levels and premature cognitive impairment/dementia in type 2 diabetes. World J Diabetes. 2016; 7:615-20.

77. Businaro R, Ippoliti F, Ricci S, Canitano N, Fuso A. Alzheimer's disease promotion by obesity: induced mechanisms-molecular links and perspectives. Current Gerontology \& Geriatrics Research. 2012; 2012:986823.

78. Arnoldussen IA, Kiliaan AJ, Gustafson DR. Obesity and dementia: adipokines interact with the brain. Eur Neuropsychopharmacol. 2014; 24:1982-99.

79. Garcia-Casares N, Garcia-Arnes JA, Rioja J, Ariza MJ, Gutierrez A, Alfaro F, Nabrozidis A, Gonzalez-Alegre P, Gonzalez-Santos P. Alzheimer's like brain changes correlate with low adiponectin plasma levels in type 2 diabetic patients. J Diabetes Complications. 2016; 30:281-6.

80. Labad J, Price JF, Strachan MW, Deary IJ, Seckl JR, Sattar N, Reynolds RM. Serum leptin and cognitive function in people with type 2 diabetes. Neurobiology of Aging. 2012; 33:2938-41.
81. Brands AM, Biessels GJ, de Haan EH, Kappelle LJ, Kessels RP. The effects of type 1 diabetes on cognitive performance: a meta-analysis. Diabetes Care. 2005; 28:726-35.

82. Simsrobinson C, Kim B, Rosko A, Feldman EL. How does diabetes accelerate Alzheimer disease pathology? Nature Reviews Neurology. 2010; 6:551-9.

83. Blennow K, Hampel H. CSF markers for incipient Alzheimer's disease. Lancet Neurology. 2003; 2:605-13.

84. Moran C, Beare R, Phan TG, Bruce DG, Callisaya ML, Srikanth V. Type 2 diabetes mellitus and biomarkers of neurodegeneration. Neurology. 2015; 85:1123-30.

85. Heijer TD, Vermeer SE, Dijk EJV, Prins ND, Koudstaal PJ, Hofman A, Breteler MMB. Type 2 diabetes and atrophy of medial temporal lobe structures on brain MRI. Diabetologia. 2003; 46:1604-10.

86. Brundel M, van den Heuvel M, de Bresser J, Kappelle LJ, Biessels GJ, Utrecht Diabetic Encephalopathy Study Group. Cerebral cortical thickness in patients with type 2 diabetes. Journal of the Neurological Sciences. 2010; 299:126.

87. Chen Z, Li L, Sun J, Ma L. Mapping the brain in type II diabetes: Voxel-based morphometry using DARTEL. European Journal of Radiology. 2012; 81:1870-6.

88. Moran C. Brain Atrophy in Type 2 Diabetes. 2013.

89. Hempel R, Onopa R, Convit A. Type 2 diabetes affects hippocampus volume differentially in men and women. Diabetes/metabolism Research \& Reviews. 2012; 28:76-83.

90. Hayashi K, Kurioka S, Yamaguchi T, Morita M, Kanazawa I, Takase H, Wada A, Kitagaki H, Nagai A, Bokura H, Yamaguchi S, Sugimoto T. Association of cognitive dysfunction with hippocampal atrophy in elderly Japanese people with type 2 diabetes. Diabetes Res Clin Pract. 2011; 94:180-5.

91. Zhang Y, Zhang X, Zhang J, Liu C, Yuan Q, Yin X, Wei L, Cui J, Tao R, Wei P, Wang J. Gray matter volume abnormalities in type 2 diabetes mellitus with and without mild cognitive impairment. Neurosci Lett. 2014; 562:1-6.

92. Manschot SM, Brands AM, van der Grond J, Kessels RP, Algra A, Kappelle LJ, Biessels GJ, Utrecht Diabetic Encephalopathy Study Group. Brain magnetic resonance imaging correlates of impaired cognition in patients with type 2 diabetes. Diabetes. 2006; 55:1106-13.

93. van Harten B, Oosterman J, Muslimovic D, van Loon BJ, Scheltens P, Weinstein HC. Cognitive impairment and MRI correlates in the elderly patients with type 2 diabetes mellitus. Age Ageing. 2007; 36:164-70.

94. Musen G, Jacobson AM, Bolo NR, Simonson DC, Shenton ME, Mccartney RL, Flores VL, Hoogenboom WS. Restingstate brain functional connectivity is altered in type 2 diabetes. Diabetes. 2012; 61:2375-9.

95. Chen YC, Jiao Y, Cui Y, Shang SA, Ding J, Feng Y, Song W, Ju SH, Teng GJ. Aberrant brain functional connectivity related to insulin resistance in type 2 diabetes: a restingstate fMRI study. Diabetes Care. 2014; 37:1689. 
96. Marder TJ, Flores VL, Bolo NR, Hoogenboom WS, Simonson DC, Jacobson AM, Foote SE, Shenton ME, Sperling RA, Musen G. Task-induced brain activity patterns in type 2 diabetes: a potential biomarker for cognitive decline. Diabetes. 2014; 63:3112-9.

97. Chen Y, Liu Z, Wang A, Zhang J, Zhang S, Qi D, Chen K, Zhang Z. Dysfunctional organization of default mode network before memory impairments in type 2 diabetes. Psychoneuroendocrinology. 2016; 74:141-8.

98. Yang SQ, Xu ZP, Xiong Y, Zhan YF, Guo LY, Zhang S, Jiang RF, Yao YH, Qin YY, Wang JZ, Liu Y, Zhu WZ. Altered Intranetwork and Internetwork Functional Connectivity in Type 2 Diabetes Mellitus With and Without Cognitive Impairment. Sci Rep. 2016; 6:32980.

99. Zeng K, Wang Y, Ouyang G, Bian Z, Wang L, Li X. Complex network analysis of resting state EEG in amnestic mild cognitive impairment patients with type 2 diabetes. Front Comput Neurosci. 2015; 9:133.

100. Nagalski A, Kozinski K, Wisniewska MB. Metabolic pathways in the periphery and brain: contribution to mental disorders? International Journal of Biochemistry \& Cell Biology. 2016; 80:19-30.

101. Duarte JM. Metabolic Alterations Associated to Brain Dysfunction in Diabetes. Aging \& Disease. 2015; 6:304-21.

102. Cao Z, Bi-Di YE, Shen ZW, Cheng XF, Yang ZX, Liu YY, Ren-Hua WU, Geng K, Xiao YY. 2D-1H proton magnetic resonance spectroscopic imaging study on brain metabolite alterations in patients with diabetic hypertension. Molecular Medicine Reports. 2015; 11:4232-8.

103. Wang Y, Xu XY, Feng CH, Li YL, Ge X, Zong GL, Wang YB, Feng B, Zhang P. Patients with type 2 diabetes exhibit cognitive impairment with changes of metabolite concentration in the left hippocampus. Metab Brain Dis. 2015; 30:1027-34.

104. Lyoo IK, Yoon SJ, Musen G, Simonson DC, Weinger K, Bolo N, Ryan CM, Kim JE, Renshaw PF, Jacobson AM. Altered prefrontal glutamate-glutamine-gammaaminobutyric acid levels and relation to low cognitive performance and depressive symptoms in type 1 diabetes mellitus. Archives of General Psychiatry. 2009; 66:878-87.

105. Tiehuis A, van der Meer F, Mali W, Pleizier M, Biessels GJ, Kappelle J, Luijten P. MR spectroscopy of cerebral white matter in type 2 diabetes; no association with clinical variables and cognitive performance. Neuroradiology. 2010; $52: 155-61$.
106. Tseng CF, Lin CC, Huang HY, Liu HC, Mao SJ. Antioxidant role of human haptoglobin. Proteomics. 2004; 4:2221-8.

107. Cocciolo A, Domenico FD, Coccia R, Fiorini A, Cai J, Pierce WM, Mecocci P, Butterfield DA, Perluigi M. Decreased expression and increased oxidation of plasma haptoglobin in Alzheimer disease: Insights from redox proteomics. Free Radical Biology \& Medicine. 2012; 53:1868-76.

108. Guerrero-Berroa E, Ravona-Springer R, Heymann A, Schmeidler J, Levy A, Leroith D, Beeri MS. Haptoglobin genotype modulates the relationships of glycaemic control with cognitive function in elderly individuals with type 2 diabetes. Diabetologia. 2015; 58:736-44.

109. Daborg J, von Otter M, Sjölander A, Nilsson S, Minthon L, Gustafson DR, Skoog I, Blennow K, Zetterberg H. Association of the RAGE G82S polymorphism with Alzheimer's disease. Journal of Neural Transmission. 2010; 117:861-7.

110. Dhar S, Ray S, Dutta A, Sengupta B, Chakrabarti S. Polymorphism of ACE gene as the genetic predisposition of coronary artery disease in Eastern India. Indian Heart Journal. 2012; 64:576-81.

111. Tian S, Han J, Huang R, Xia W, Sun J, Cai R, Dong X, Shen Y, Wang S. Association of Increased Serum ACE Activity with Logical Memory Ability in Type 2 Diabetic Patients with Mild Cognitive Impairment. Front Behav Neurosci. 2016; 10:239.

112. Jordan BD. Genetic influences on outcome following traumatic brain injury. Neurochemical Research. 2007; 32:905.

113. Xu ZP, Yang SL, Zhao S, Zheng CH, Li HH, Zhang Y, Huang RX, Li MZ, Gao Y, Zhang SJ, Zhan PY, Zhang LF, Deng L, et al. Biomarkers for Early Diagnostic of Mild Cognitive Impairment in Type-2 Diabetes Patients: A Multicentre, Retrospective, Nested Case-Control Study. EBioMedicine. 2016; 5:105-13.

114. Jacobson AM, Paterson AD, Ryan CM, Cleary PA, Waberski BH, Weinger K, Musen G, Dahms W, Bayless M, Silvers N, Harth J, Boright AP, DCCT/EDIC Research Group. The associations of apolipoprotein $\mathrm{E}$ and angiotensin-converting enzyme polymorphisms and cognitive function in Type 1 diabetes based on an 18-year follow-up of the DCCT cohort. Diabetic Medicine. 2010; 27:15-22. 